AperTO - Archivio Istituzionale Open Access dell'Università di Torino

Late persistence and deterministic extinction of "humid thermophilous plant taxa of East Asian affinity" (HUTEA) in southern Europe

This is a pre print version of the following article:

Original Citation:

Availability:

This version is available http://hdl.handle.net/2318/1575639

since 2017-05-17T18:04:30Z

Published version:

DOI:10.1016/j.palaeo.2015.08.015

Terms of use:

Open Access

Anyone can freely access the full text of works made available as "Open Access". Works made available under a Creative Commons license can be used according to the terms and conditions of said license. Use of all other works requires consent of the right holder (author or publisher) if not exempted from copyright protection by the applicable law. 
This Accepted Author Manuscript (AAM) is copyrighted and published by Elsevier. It is posted here by agreement between Elsevier and the University of Turin. Changes resulting from the publishing process - such as editing, corrections, structural formatting, and other quality control mechanisms - may not be reflected in this version of the text. The definitive version of the text was subsequently published in PALAEOGEOGRAPHY

PALAEOCLIMATOLOGY PALAEOECOLOGY, None, 2015, 10.1016/j.palaeo.2015.08.015.

You may download, copy and otherwise use the AAM for non-commercial purposes provided that your license is limited by the following restrictions:

(1) You may use this AAM for non-commercial purposes only under the terms of the CC-BY-NC-ND license.

(2) The integrity of the work and identification of the author, copyright owner, and publisher must be preserved in any copy.

(3) You must attribute this AAM in the following format: Creative Commons BY-NC-ND license (http://creativecommons.org/licenses/by-nc-nd/4.0/deed.en),

10.1016/j.palaeo.2015.08.015

The publisher's version is available at:

http://linkinghub.elsevier.com/retrieve/pii/S0031018215004514

When citing, please refer to the published version.

Link to this full text:

http://hdl.handle.net/2318/1575639 


\title{
Late persistence and deterministic extinction of "humid thermophilous plant taxa of East Asian affinity" (HUTEA) in southern Europe
}

\author{
Edoardo Martinetto ${ }^{1}$, Arata Momohara ${ }^{2}$, Roberto Bizzarri ${ }^{3}$, Angela Baldanza ${ }^{3}$, Massimo Delfino ${ }^{1,4}$, \\ Daniela Esu ${ }^{5}$, Raffaele Sardella ${ }^{5}$
}

1 - Dipartimento di Science della Terra, Università di Torino, via T. Valperga Caluso 35, I-10125

Torino, Italy.

2 - Graduate School of Horticulture, Chiba University, 648 Masudo, Chiba 271-8510, Japan.

3 - Dipartimento di Fisica e Geologia, Università di Perugia, Via A. Pascoli snc, I-06123 Perugia, Italy.

4 - Institut Català de Paleontologia Miquel Crusafont, Universitat Autònoma de Barcelona, Edifici Z (ICTA-ICP), Carrer de les Columnes s/n, Campus de la UAB, E-08193 Cerdanyola del Valles, Barcelona, Spain

5 - Dipartimento di Scienze della Terra, Sapienza Università di Roma, Piazzale Aldo Moro snc, Roma, Italy.

Key words

carpological remains, phytogeographic-climatic characterization, exotic elements, climate change, late Cenozoic, Italy

Abstract

Several terrestrial plant fossils found in the late Cenozoic of Europe belong to thermophilous genera or infrageneric taxa which do not grow in this continent today, and are usually called "exotic elements". Within this large group we singled out three more precisely defined categories based on the hypothesis that the change of geographic distribution between the late Cenozoic and the present is the result of deterministic extinctions caused by climate change. Among the taxa shared by the modern East Asian and the Plio-Pleistocene European flora, the "humid thermophilous taxa of East Asian affinity" (HUTEA) represent the central category in our study. These were traditionally considered "Pliocene" elements in Europe. In our analysis of 13 reliably dated Italian assemblages the percentage of species belonging to the HUTEA category was found to be higher in Pliocene sites, and very low to null in Pleistocene ones. Also early Pleistocene assemblages across all of Europe did not contain any HUTEA, apart from Eucommia, and Glyptostrobus and Symplocos sect. Lodhra in the refugial area of the Colchis.

Our analysis of fruit and seed assemblages in the San Lazzaro section (Umbria, central Italy), recently assigned to the early Pleistocene, provided contrasting evidence, which required a reconsideration of the stratigraphic and palaeontological context of two well known sites in central Italy, Cava Toppetti II and Dunarobba. Using vertebrate and continental mollusc biochronology the age of these sections was established and they were compared with other assemblages in central Italy and Europe. We show that in central Italy at least three HUTEA species (Sinomenium cantalense, Symplocos casparyi, Toddalia rhenana) persisted after the Pliocene/Pleistocene boundary. We conclude that central-southern Italy offered a refugial niche that was warm and wet enough to assure the longer survival of some HUTEA, in contrast to central Europe.

\section{Introduction}

In the course of the stratigraphical and palaeontological study of the San Lazzaro section in central Italy (Fig. 1), recently assigned to the early Pleistocene (Baldanza et al., 2014), one of us (A.B.) found an endocarp of Sinomenium cantalense. The finding of this species, readily assignable to the humid thermophilous taxa of East Asian affinity in an early Pleistocene section was the starting point for further collecting efforts to find evidence for the role of central Italy as a centre of refuge for such thermophilous taxa in the Plio-Pleistocene (Martinetto, 2001a). In this paper we adopt the 
definition of the Pliocene and Pleistocene of Gibbard et al. (2010), with the boundary fixed at 2.6 $\mathrm{Ma}$, and we accept their indication for the chronologic boundaries of the four stages Zanclean, Piacenzian, Gelasian and Calabrian. Therefore, the terms middle Pliocene, late Pliocene and early Pleistocene used in previous works (among others, Ambrosetti et al., 1995a, 1995b; Abbazzi et al., 1997; Martinetto, 2001a) have a chronologic connotation which differs from that adopted here.

It is well known that many plant fossils found in the late Cenozoic of Europe belong to thermophilous genera or infrageneric taxa which do not grow in this continent today (Mai, 1989; Qian et al., 2006; Rodriguez Sanchez and Arroyo, 2008). Such fossils are usually called "exotic elements" (Reid, 1920) and this term corresponds more or less with "extinct plants" for the PlioPleistocene interval (Svenning, 2003). The climatic requirements are not considered in the definition of both exotic and extinct; however, several attempts have been made to assign the exotic (or extinct) elements to a few distinct plant groups that involve a climatic characterization and/or a phytogeographic aspect (Mai, 1989, 1991, 1995a; Grichuk, 1997; Grimsson et al., 2015). Examples of names which have been used include: "Palaeotropical flora/element", "Arcto-Tertiary" or "Arctotertiary flora/element" (Engler, 1879-1882; Mai, 1989, 1991; Grimsson et al., 2015), "subtropical elements" (Mai, 1970; Zagwijn, 1990), "Mastixioideen" (Kirchheimer, 1957; Mai, 1964), "Boreotropical flora" (Wolfe, 1975), "Taxodiaceae group" (Bertoldi et al., 1994), "Tethyan plants (or Tethys flora)" (Szafer, 1961; Mai, 1989; Rodriguez Sanchez and Arroyo, 2008), "Megamesothermic elements" (e.g. Popescu et al., 2010), "humid subtropical elements" (Bertini and Martinetto, 2011). All these names leave some uncertainty as to what is included and what is excluded from the definition, firstly because the phytogeographic information, both past and present, is superimposed to, and variously interfingers with, the climatic one, and secondly because of the very difficult, not unambiguous, climatic characterisation of the fossil-taxa (Kvaček, 2007; Grimm and Denk, 2012; Utescher et al., 2014). Also the modern reference models may be ambiguous, for example the qualitative term "subtropical" is used with very different temperature boundaries by Chinese (e.g. Hou, 1983) and Japanese authors (e.g. Kira, 1991).

The different extant distribution of plant taxa that grew together in the Cenozoic of Europe have often been given considerable relevance in the analysis of palaeofloras (see Reid and Reid, 1915; Szafer, 1961; Mai, 1964, 1989, 1995a). However, in our opinion most previous analyses and descriptions of the floral change in the Plio-Pleistocene of Europe suffered from the lack of precisely defined categories whose chronological analysis would adequately point out timing and entity of the large Plio-Pleistocene mass extinction (Tallis, 1991; Svenning, 2003). Additionally, the descriptions of Plio-Pleistocene floral changes mostly relied on pollen data (e.g. Tzedakis et al., 2006; Postigo-Mijarra et al., 2009; Magri, 2010; Orain et al., 2013), particularly in Italy (Bertini, 2010; Combourieu-Nebout et al., 2015). However, by combining pollen and carpological records (Bertini and Martinetto, 2011) it was noticed that pollen assemblages mainly reflect anemophilous plants, while they do not accurately represent the assemblages of "subtropical humid forest" type (sensu Hou, 1983, and Bertini and Martinetto, 2011), which are very rich in entomophilous plants and were present in southern Europe right at the time when major extinction events are hypothesized (Bertini and Martinetto, 2011). As recently confirmed by Goring et al. (2013), taxa that are pollinated by insect or animal vectors (entomophilous or zoophilous, respectively), and species with limited dispersal ability are rarely recorded in fossil pollen records. Some works on modern fruit and seed assemblages (e.g. Thomasson, 1991; Vassio and Martinetto, 2012 and references therein) indicate a less biased representation of plant diversity, in particular for several enthomophilous (e.g. Actinidia, Frangula, Paulownia, Rubus, Sambucus) and herbaceous plants (e.g. Ajuga, Cyperaceae, Hypericum, Potamogeton, etc.). For these taxa, the plant elements that enter the fossil record and allow species-level identification are fruits and/or seeds. Thus, the works which exclude carpological data definitely underestimate past plant species diversity and the extent of Plio-Pleistocene plant extinctions, and the focus of this paper will be on fossil fruits and seeds.

The analysis of the San Lazzaro material led us to reconsider the bulk of information accumulated for the Italian late Cenozoic fruit and seed assemblages in the last 30 years (in particular: Gregor, 
1990; Martinetto, 1994, 1995, 1999, 2001a, 2001b, 2009, in press; Bertoldi and Martinetto, 1995; Mai, 1995b; Basilici et al., 1997; Ghiotto, 2010; Martinetto et al., 2007, 2015). Consequently, we felt the need to introduce precisely defined categories, which would permit us to better appreciate the chronological steps of the dramatic southern European floral change in the Plio-Pleistocene. One of the necessary operations was to combine in a clear manner the modern phytogeography and the climatic requirements of several taxa. Therefore, we focused on geographical and ecological characteristics of modern relatives of fossil taxa: partly shared geographic range, minimum thermic tolerance and moisture requirement. Since the geographic area where most of the "exotic" taxa of the European late Cenozoic are still living today is definitely East Asia (Tralau, 1963; Martinetto, 1998; Qian et al., 2006; Manchester et al., 2009), we considered it to be important for the definition of the new categories.

\subsection{Definition of "humid thermophilous extinct European taxa of East Asian affinity" (HUTEA)}

The taxonomic similarity between Neogene European floras and modern East Asian ones arerooted at least into the Miocene (Mai, 1989). As known from various studies at a global and regional scale, Cenozoic climates were generally warmer and more humid than at present, and were characterized by shallow latitudinal gradients (Utescher et al., 2011 and references therein). Several authors (Bruch et al., 2011, Liu et al., 2011, Xing et al., 2012; Jacques et al., 2013) pointed out that the climate was wetter and warmer than the present one during the Miocene in both central Europe and China. Even central and northern Eurasian areas, such as Kazakhstan (Bruch and Zhilin, 2006) and Siberia (Popova et al., 2012), were wetter and warmer during the Miocene, despite the relatively higher seasonality and continentality.

This climatic situation was probably suitable for the formation of latitudinal vegetation belts with a similar floristic composition in both western and eastern Eurasia (Mai, 1989, 1991; Kovar-Eder et al., 2008), and strong floristic affinities with East Asia have also been encountered for North American floras (Liu and Jacques, 2010). Several authors explained that the modern East Asian woody flora is richer than the European (and North American) one (e.g., Kubitzki and Krutzsch, 1996; Manchester, 1999; Tiffney and Manchester, 2001; Wen, 1999; Wen et al., 2010) mainly due to a minor impact of extinctions, even if several woody species got extinct also in East Asia during the Plio-Pleistocene (Momohara, 2015).

Some close relatives of most European extinct species were already present in the warm temperate belt of East Asia before the Pliocene (e.g., Cathaya, Cephalotaxus, Craigia, Cryptomeria, Cyclocarya, Eucommia, Ginkgo, Glyptostrobus, Pseudolarix, Taiwania: Manchester et al., 2009) or possibly migrated there during the Pliocene (e.g., Hemiptelea, Rehderodendron: Manchester et al., 2009), and could survive the Pleistocene climatic crisis because of the presence of niches that were wet (atmospheric humidity) and warm enough, even in sites not related to rivers and swamps. Based on the concept of "physiological uniformitarianism" (Tiffney and Manchester, 2001) we can assume that the climatic tolerances of the living relatives of Neogene European taxa that survived in the humid and warm temperate to tropical areas of East Asia roughly correspond (maybe only in part) to those of the extinct European forms of the same genus, subgenus or section. Svenning (2003) pointed out a deterministic effect in late Cenozoic plant extinctions and recognized three important groups of taxa for the analysis of the ancient European floras: 1) widespread taxa; 2) relictual taxa; 3) extinct taxa. In referring to extinct taxa, Svenning (2003) restricted his analysis to cool-temperate tree genera, but recently Eiserhardt et al. (2015) carried out an analysis on more thermophilous plants. Actually, several Plio-Pleistocene taxa occurring in Europe are more thermophilous than "cool-temperate" (Martinetto et al., 2015) so that we now consider it important to single out a new group of thermophilous taxa with a partly shared (as for eastern Asia) current distribution outside Europe and a common, definite climatic boundary. The thermophilous characterization of several taxa documented by fossils is provided by the minimum Mean Annual Temperature (MAT) requirement of their modern relatives (Table 1). 
Consequently, we define as "HUmid Thermophilous extinct European taxa of East Asian affinity", in short HUTEA, those plant taxa which have well-documented fossil records in the late Cenozoic of Europe, which do not grow spontaneously in this continent and West Asia at present (unless as aliens), which do not tolerate a Mean Annual Temperature below $8^{\circ} \mathrm{C}$ and a Mean Annual Precipitation (MAP) below ca. $800-1000 \mathrm{~mm} /$ year, and which belong to genera or infrageneric taxa that presently grow in East Asia (Wang, 1961; Qian et al., 2006; Manchester et al., 2009; Fang et al., 2009, 2011; Grimm and Denk, 2012; Eiserhardt et al., 2015; Utescher and Mosbrugger, 2015). We single out the $8^{\circ} \mathrm{C}$ value of MAT because this is the boundary of the distribution of boreal (subarctic) and thermophilous (temperate) taxa in East Asia. The lower limit of fir and spruce forest and the upper limit of deciduous forest is $7.8{ }^{\circ} \mathrm{C}$ MAT in China (Fang and Yoda, 1989). Although the lower MAT limit of the thermophilous evergreen arboreal Fagaceae and Lauraceae (dominant tall trees of temperate broadleaved evergreen forests in East Asia) is between 9 and $12^{\circ} \mathrm{C}$ (Hattori and Nakanishi, 1985; Fang and Yoda, 1989; Fang et al., 2011), we decided that adding $1{ }^{\circ} \mathrm{C}$ of tolerance would admit sporadic occurrences of thermophilous plants above the $9{ }^{\circ} \mathrm{C}$ MAT isotherm. The focus on MAT for the definition of the HUTEA is justified by the large availability of data (Grimm and Denk, 2012; Utescher and Mosbrugger, 2015) for most of the plant genera documented by fossils in Europe, and by the determinant role of this parameter for plant extinction or survival in the late Cenozoic of Europe (Svenning, 2003; Eiserhart et al., 2015). Conversely, we did not manage to gather precise values of minimum precipitation requirements for all the exotic Neogene plant taxa of Europe; nevertheless we consider important to include in the HUTEA definition a rule that excludes those plants which tolerate a low precipitation (below ca. $800-1000 \mathrm{~mm} / \mathrm{year}$ ). In fact it has been pointed out that the extinction of several Neogene taxa in Europe dependended from a scarce tolerance not only of low temperature, but also of low precipitation (Svenning, 2003; Eiserhart et al., 2015). The thermophilous genera that survived in southern Europe until present time (e.g. Laurus, Olea) are mainly adapted to dry (Mediterranean) climate, whereas several thermophilous genera extinct in Europe are now growing in areas affected by the East Asian Monsoon that supplies higher precipitation to plants during the growing season. In East Asia the main evergreen forest formation, dominated by Fagaceae and Lauraceae, is called "lucidophyllous forest" and differs from the south European (Mediterranean) sclerophyllous forest formation by its less xeromorphic characteristics, such as larger shiny leaves, larger tree size and higher species diversity with many epiphytes and woody lianas (Kira, 1991).

We are aware that other parameters (e.g. Warmth Index, Coldness Index; Kira, 1991) could be more appropriate to define a category such as HUTEA. Nevertheless, the minimum MAT requirement is an important factor determining the possibility for a plant taxon to overcome a climatic bottleneck. The climatic characteristics of the refugia might have been been decisive for the possibility of a plant species to survive (Magri, 2010; Gavin et al., 2014) and obviously it would have gone extinct if its minimal thermal or humidity requirements would no longer have been present in the last refugium. In this respect, groups of taxa with similar requirements may be expected to go extinct together (Tallis, 1991; Grichuk, 1997; Eiserhardt et al., 2015). However, some extinctions are certainly controlled by complex and multiple factors. For example it has been suggested that Cedrus (Su et al., 2013) and Sequoia (Zhang et al., 2015) disappeared from China because of seed ecological aspects, triggered by climate change.

Three examples, concerning genera which do not tolerate a MAT below $8^{\circ} \mathrm{C}$ (Table 1 ), may be useful to support the above definition of HUTEA: Toddalia is assigned to the HUTEA because it is distributed in the tropical-warm temperate zone of East Asia and in Africa, but not in Europe and West Asia (Gregor, 1979). Symplocos sect. Lodhra is assigned to the HUTEA because it is distributed in the tropical-warm temperate zone of East Asia, but not in Europe and West Asia (Fritsch et al., 2015). Rehderodendron is assigned to the HUTEA because it is distributed only in the "subtropical" zone (sensu Hou, 1983) of East Asia. 
The genera Cathaya and Pseudolarix meet all the requirements to be classified as HUTEA, but they are excluded for their present highly relictual distribution, which may provide an inaccurate representation of their past climatic requirements, similarly as for Tetraclinis (Kvaček, 2007). Azolla is not considered a HUTEA because it is a water plant rather independent from atmospheric humidity.

\section{(TABLE 1 approximately here)}

According to the above definition and to the data (e.g., minimum thermic requirements: MATmin) reported in Table 1, the following HUTEA have so far been documented for the late Cenozoic of Italy (Martinetto, 1995, 1998, 1999, 2001a; 2001b; Follieri, 2010; Martinetto et al., 2015): Amentotaxus, Cephalanthus, Cinnamomum, Craigia, Cyclea, Cyclocarya, Ehretia, Engelhardia, Eucommia, Glyptostrobus, Mallotus, Meliosma subgen. Kingsboroughia, Paulownia, Rehderodendron, Sabia, Sargentodoxa, Saurauia, Sinomenium, Stemona, Symplocos sect. Lodhra, Taiwania, Ternstroemia, Tetrastigma, Toddalia, Trichosanthes, Turpinia and Wikstroemia.

\subsection{Other categories (CTEA, TEWA)}

Other taxa documented in the late Cenozoic of southern Europe have the correct geographic distribution nowadays to be considered HUTEA (i.e. embracing East Asia and excluding Europe and West Asia), but they are not considered, because the modern representatives do tolerate a Mean Annual Temperature below $8^{\circ} \mathrm{C}$ (e.g. Actinidia, Alangium, Ampelopsis, etc.: Table 1). These taxa will be named CTEA ("Cool-Tolerant extinct European taxa of East Asian affinity") in this paper and belong to the somehow ambiguous [changing on the basis of the extent of territory considered] category of the "exotic" taxa (Reid, 1920; see the more precisely defined "category E" in Martinetto, in press).

The HUTEA category already has a satisfactory climatic connotation, which we deem to be useful for an analysis of the climatic determinism in their extinction. Conversely, the CTEA category certainly contains a very heterogeneous mix of species with different climatic tolerances. In fact, Magnolia provides a good example of a cool-tolerant CTEA genus that contains several modern species (Grimm and Denk, 2012; Mosbrugger and Utescher, 2015), which are absolutely thermophilous and not cool-tolerant (tropical-subtropical). Similarly, a diversified climate tolerance has been also hypothesized for different European fossil-species (Mai, 1975). Given this situation, it is not surprising that several CTEA would show a HUTEA-like extinction pattern. However, in this paper our attention has been focused on the species that show a delayed disappearance time in comparison to the HUTEA.

Finally, a few taxa which do not tolerate a MAT below $8^{\circ} \mathrm{C}$ are not assigned to the HUTEA because of the modern geographic range: Coriaria, Datisca, Ficus, Laurus, Liquidambar, Morella, Ocotea, Olea, Platanus, Sideroxylon, Styrax, Tetraclinis and Visnea grow in southern Europe, North Africa (incl. Macaronesia) and/or West Asia. These taxa will be indicated as TEWA, Thermophilous European, West Asian and/or African elements, in this paper. Pterocarya, Parrotia and Zelkova are not assigned to the HUTEA nor to the CTEA or TEWA, because they grow in relict niches of south-eastern Europe and/or West Asia (southern shores of the Black Sea and Caspian Sea), commonly including sites with a Mean Annual Temperature below $8^{\circ} \mathrm{C}$.

Finally, late Cenozoic south European taxa that today only survive in America are not many (Decodon, Dulichium, Leitneria, Proserpinaca, Sequoia, Taxodium) and will not be specifically dealt with in this paper.

It is apparent that the HUTEA and CTEA concepts have much to do with a change of geographic distribution between the Plio-Pleistocene and the present. The main aim of this work is to present new fossil data from Italy and an updated state-of-the-art regarding the timing of disappearance of 
HUTEA and CTEA species from Europe. Furthermore, we newly consider the possibility of deterministic extinctions (Svenning, 2003; Eiserhardt et al., 2015).

\section{Geological setting}

The post-Miocene, NW-SE oriented South Valdichiana Basin (Fig. 1), enclosed between the MesoCenozoic Rapolano-Mt. Cetona and Narnese-Amerina Apennine anticlines and bounded by extensional faults, occupies a wide area between south-eastern Tuscany and western Umbria, in central Italy. In the Pliocene-Pleistocene interval, the Narnese-Amerina ridge separated the mainly marine domain of South Valdichiana from the continental deposits of the Southern Tiberino Basin (Figs. 1, 2), while, during the early Pleistocene, a wide delta in what is now the Città della Pieve area divided the continental (northwards) and the marine Valdichiana (southwards) (Bizzarri and Baldanza, 2009; Bizzarri et al., 2015).

\section{(FIGURE 1 approximately here)}

South Valdichiana marine deposits in the study area, including the San Lazzaro section (Fig. 1), clearly mark a regressive trend, from offshore transition silty sands to lower shoreface sands, and finally to a gravel beachface with evidence of a river mouth in the uppermost part (Baldanza et al., 2011). The same main trend is recognized in other sections nearby, such as the Monteleone section and the Città della Pieve section (Bizzarri and Baldanza, 2009). All these sections are referred to alternatively river- and wave-dominated shallow coastal marine environments (Bizzarri et al., 2015), and attributed to the "Deltaic coast" inside the "Chiani-Tevere" Unit (Fig. 2, Baldanza et al., 2014; Martinetto et al., 2014). On the other hand, through late Pliocene and early Pleistocene, the Southern Tiberino Basin evolved from a wide lacustrine environment to a river-drained valley system (Ambrosetti et al., 1995a; Basilici, 1997, 2000a, 2000b; Martinetto et al., 2014). The sections Cava Toppetti II (Abbazzi et al., 1997) and Dunarobba (Ambrosetti et al., 1995b) are representative of this second context.

\section{Materials and methods}

(FIGURE 2 approximately here)

This work integrates the analysis of freshly collected material from the San Lazzaro section with the reinterpretation of the stratigraphic and palaeontological data from the sites Cava Toppetti II (Abbazzi et al., 1997; Argenti, 1999, 2004; Martinetto, 2001a; Petronio et al., 2003; Sardella et al., 2003) and Dunarobba (Ciangherotti et al., 1998; Manganelli and Giusti, 2000; Manganelli et al., 2008; Martinetto et al., 2014).

In the San Lazzaro section, as well as in the neighbouring sections (Fig. 3), a close, about $1 \mathrm{~m}$ spaced, sampling for marine microfossils ("biostratigraphic samples") was carried out in the lowermost deposits, in order to provide an integrated biostratigraphical datum. Similarly, more widely spaced biostratigraphic samples were collected in the upper part of the section, in correspondence of fine-grained deposits. For each sample, $100 \mathrm{~g}$ of sediment were processed with $\mathrm{H}_{2} \mathrm{O}_{2}$ solution, washed through a $63 \mu$ size mesh, and the residue observed using a stereomicroscope. Smear slides for nannoplankton analysis were prepared using the standard technique proposed by Bown and Young (1998), and observed under a polarizing-light microscope at $1000 x$ magnification.

\section{(FIGURE 3 approximately here)}

The above-mentioned finding, in a biostratigraphic bulk sample (FU6, ca. $100 \mathrm{~g}$ ) collected at $14 \mathrm{~m}$, of a fruit part (endocarp) of Sinomenium cantalense was the starting point for a more extensive sampling effort in the San Lazzaro section. A few concentrations of compressed plant fragments were noticed in the portion from $5.5 \mathrm{~m}$ to $8.5 \mathrm{~m}$ of the section (Fig. 4), and three bulk sediment samples FU3 and FU4, ca. 400 g, and FU5, ca. 2000 g; these are named "carpological samples") have been collected there and processed with the palaeocarpological method illustrated in Basilici et al. (1997).

The methods for the identification of plant materials are the same as those recently described in Martinetto et al. (2015). However, the climatic characterisation of each plant fossil-species was 
carried out differently. We did not use only the data available in the Paleoflora Database (PFDB: Utescher and Mosbrugger, 2015) and in the GrimClim Database (CG: Grimm and Denk, 2012), because these data have several biases depending from their literature sources: the PFDB does not indicate references for the thermal boundary values referred to each taxon, and the boundary temperatures of Fang (2011), largely used by the CG, were defined from very rough distribution data at county level (several Chinese provinces are larger than Japan). Therefore, whenever possible, we used in Table 1 the more precise data from different literature sources (Alternative MATmin in Appendix 1). Those include local floras and vegetation survey reports in China and Japan, in which distribution of taxa are described and/or mapped on the altitudinal scale of at least $100 \mathrm{~m}$ based on herbarium specimens and/or field observations (Appendix 1).

\section{(FIGURE 4 approximately here)}

Deposits in the area of Fabro Scalo (Fig. 1) have been investigated with the aim to: 1) reconstruct a lithostratigraphic section for the area, 2) better document the palaeofloral assemblages inside the phytodebris-rich horizons of the San Lazzaro outcrop, 3) establish the age of these deposits, and 4) compare the plant assemblages with other possibly coeval assemblages in central Italy, first of all those of the dated Cava Toppetti II section (Abbazzi et al., 1997; Martinetto, 2001a), and secondly those of poorly dated Dunarobba succession (Martinetto et al., 2014). To reevaluate the age of these three sections, data on vertebrate and continental mollusc biochronology were reconsidered (Abbazzi et al., 1997; Gliozzi et al., 1997; Ciangherotti et al., 1998; Petronio et al., 2003; Sardella et al., 2003; Argenti, 2004; Manganelli et al., 2008).

In addition, continental mollusc and vertebrate records were investigated as complementary palaeoclimatic evidence to terrestrial plants. In particular we analysed the history of the HUTEA plants in parallel with that of the terrestrial ectothermic vertebrates, whose distribution is clearly related to historical variations of temperature and humidity more directly than that of other vertebrates (Delfino, 2002; Kotsakis et al., 2004; Venczel and Sanchiz, 2005; Delfino et al., 2006; Delfino and Sala, 2007; Piras et al., 2007; Delfino et al., 2008).

Even if we base our analysis on the climatic determinism of plant extinctions, the correlation of the disapperance events with the standard climatic curves (e.g. Zachos et al., 2001; Lisecki and Raymo, 2005; De Shepper et al., 2013; Prescott et al., 2014) requires more information and is beyond the scope of this work.

\subsection{Carpological and floristic analyses}

The San Lazzaro sediment samples FU3, FU4 and FU5 were prepared according to a standard palaeocarpological method (Martinetto, 1994; Basilici et al., 1997). The definition of the HUTEA category allowed us to carry out a new floristic analysis, both for the San Lazzaro assemblage and for several other Pliocene and early Pleistocene floras of Italy: we selected 13 reliably dated assemblages ( 2 of the Zanclean, 5 of the Piacenzian, 2 of the Gelasian, 3 Calabrian, 1 early Middle Pleistocene) and we analysed the percentage of species belonging to the HUTEA category, referred to the total number of species (Table 2). Furthermore, since our focus was on the early Pleistocene, we also analyzed the floral lists of all the main carpofloras of the rest of Europe (Baas, 1932; Chochieva, 1965; Buzek et al., 1985; Mai and Walther, 1988; Günther and Gregor, 1990; Velichkievich and Zastawniak, 2003; Mai and Velitzelos, 2007) whose age was proved or supposed to fall within that time interval (Table 3).

(TABLE 2 approximately here)

(TABLE 3 approximately here)

In order to get an overview of the disappearance times of themophilous plants at the south European scale, the occurrence and suggested extiction time of HUTEA were also checked in synthetic 
palynological papers dealing with the following areas: whole area (Popescu et al., 2010), Iberian peninsula (Postigo-Mijarra et al., 2009), Italy (Bertini, 2010; Magri, 2010; Combourieu-Nebout et al., 2015), Balkan Peninsula (Tsedakis et al., 2006; Biltekin et al., in press), Colchis area (Shatilova et al., 2014) and Turkey (Biltekin et al., in press).

\section{Results}

\subsection{The San Lazzaro section and its age constraints}

The composite sedimentological and stratigraphic reconstruction proposed for the Fabro Scalo area integrates old observations (Baldanza et al., 2011, 2014; Bizzarri et al., 2015) and newly collected data. The general geological and sedimentological pattern, from the base to the top, is organized as follows (Fig. 3):

- about 10 m (cropping out) of structureless, mollusc-rich clayey and silty sand (offshore transition deposits); the lowermost layers are covered by recent alluvial deposits;

- up to 30-40 m of highly fossiliferous (mainly molluscs) fine sand (lower shoreface deposits);

- up to $25 \mathrm{~m}$ of intermingled coarse sand and gravel (gravel beachface deposits);

- a minimum of $20 \mathrm{~m}$ of channelled gravel with minor sand (river mouth deposits).

The about 27 m-thick San Lazzaro section represents approximately the lower/intermediate part of this composite section (Fig. 3); deposits grade up from poorly sorted silty sand, referred to the offshore transition, to moderately sorted fine sand of lower shoreface. Throughout the section, a rich and diversified fossil record (Baldanza et al., 2014; Bizzarri et al., 2015), dominated by molluscs, echinids, lunulite bryozoans, benthic foraminifera and decapod crustaceans was documented; both macro- and micropaleontological assemblages are dominated by benthic taxa, mostly referred to warm shallow water conditions.

As for the Monteleone and the Città della Pieve sections, deposits in the Fabro Scalo area are mainly referred to the MNN 18 - MNN 19a zones (sensu Rio et al., 1990) on the basis of nannofossil assemblages: rare small-sized Gephyrocapsa spp. (sensu Raffi, 2002), Helicosphaera sellii, Calcidiscus macintyrei, very rare and broken Discoaster brouweri and Coccolithus pelagicus. Trough the composite lithostratigraphic section, two calcareous nannofossil biostratigraphic events are recognized (Fig. 3): the LO of Discoaster brouweri (top of MNN 18 zone, tDb sensu Raffi, 2002) in the lowermost part of the Fabro-Carnaiola section, and the FO of medium-sized Gephyrocapsa spp. (base of MNN19b subzone, bmG sensu Raffi, 2002) at about the top (22 m) of the San Lazzaro section. Therefore, the biostratigraphic data permit to assign deposits to the Gelasian pro parte - Calabrian p.p. interval. This transition is also marked by the occurrence, in the lowermost deposits, of marine ostracods such as Aurila cruciata, Loxoconcha glabra, Argilloecia sp., and Ruggieria longecarenata, usually documented from the end of the Gelasian and the base of the Calabrian (Faranda and Gliozzi, 2008). The occurrence, throughout Gelasian-Calabrian sections, of taxa of previously supposed "Pliocene affinity", such as Amphistegina spp. and Persististrombus cf. coronatus, is not surprising, nor sufficient to suggest an older (Piacenzian) age: in fact, the persistence of these taxa into Gelasian to Calabrian deposits has been documented in other sites of this area (Bizzarri and Baldanza, 2006; Monaco et al., 2011). The two horizons with carpological remains, inside the San Lazzaro section (Fig. 3), are attributed to the MNN 19a subzone, well inside the early Pleistocene, and are still referable to the Gelasian stage.

\subsubsection{The San Lazzaro carpological assemblage}

The preparation of the San Lazzaro carpological samples yielded plant assemblages mainly made up of woody fragments, particularly abundant in sample FU5. However, a careful observation allowed us to separate also a few, mostly fragmentary, fruits and seeds. Samples FU3 and FU4 had a very poor carpological content, reported in Table 4, whereas FU5 yielded more abundant carpological material that allowed us to identify five definite fossil-species (ICN, McNeill et al., 
2012) well-known in the Pliocene of Italy (see Table 4 for the number of specimens): Magnolia allasoniae, Sinomenium cantalense, Symplocos casparyi, Toddalia rhenana and Zanthoxylum ailanthiforme. The occurrence of 3 HUTEA out of 6 species forming the San Lazzaro plant assemblage (Table 4$)$ represents a very high percentage $(50 \%)$. So, the precise identification at species level allowed by fruit morphology give to these few remains a relevant importance, due to the stratigraphic context in which they have been found. These taxa have been described and figured in Martinetto (2001a, 2001b), Mai and Martinetto (2006) and Martinetto et al. (2014, 2015). A single species has been left in open nomenclature for the reason discussed below:

- Vitis cf. vinifera L. subsp. sylvestris Gmelin - seeds of Vitis with distinct similarities to the modern Mediterranean wild grape $V$. vinifera subsp. sylvestris are abundant in several tens of Italian fossil sites spanning from the Zanclean to the Holocene (Martinetto, 1994; Basilici et al., 1997; Cavallo and Martinetto, 2001). However, their assignment to the modern species (and subspecies) is not straightforward because a similar fossil-species has also been described (Vitis parasylvestris Kirchheimer 1957) and often reported in the Neogene of Europe (Geissert et al., 1990; Martinetto, 1994; Mai, 2001). The diagnostic features of this last species are said to be the length up to $7 \mathrm{~mm}$ and the small seed body associated to a narrow cylindrical basis, somehow similar to that of the Holocene cultivated forms of $V$. vinifera subsp. vinifera. The consistent variability of morphological characters observed in rich fossil populations makes a precise assignment at species level problematic, in the absence of a detailed statistical and morphometric study. However, the dimensions and the shape of the base in the Plio-Pleistocene Italian seeds is mostly the same as in the modern Mediterranean species, so that a major affinity to Vitis vinifera subsp. sylvestris than to $V$. parasylvestris is suggested also for the specimen of San Lazzaro.

\section{(TABLE 4 approximately here)}

\subsubsection{Taphonomical considerations}

Almost the whole carpological record of San Lazzaro comes from a thin lens of mixed shells and compressed phytodebris (FU5 in Table 4). Several lenses of this type are usually well exposed and recognizable after periods of intense rain (Fig. 5). Each lens is concave upwards, up to $40 \mathrm{~cm}$ wide, less than $10 \mathrm{~cm}$ thick, and filled by structureless clastic-bioclastic very fine sand, just a little coarser than the enclosing silty sand deposits. Mollusc shells and fragments are usually found at the bottom or in the lateral parts, while thin wood fragments are more randomly dispersed. In the 4-9.5 m interval (Fig. 3), such lenses are frequent, interposed to both shell lags and spotted mollusc specimens. Millimetric, isolated wood fragments (compressions) are locally spread through the rest of the section. A speditive anatomical analysis (stereomicroscope) proves that most of the phytodebris consists of heteroxylous and homoxylous xylem fragments, thus proving their origin from terrestrial or at least coastal woody plants. The abundance of such plant remains in a shallow marine nearshore environment probably reflects river flood events from neighboring areas. Distally, from the prodelta to the offshore marine environment, major events may trigger remobilization of sediments (sediment-gravity flows sensu Lowe, 1982 and Nemec and Steel, 1984), including density currents (turbidity currents). Several plant fragments horizons inside massive to laminated sandy sediments are interpreted as part of turbidites s.l. and even diagnostic of hyperpycnal flows (hyperpycnites: Zavala et al., 2012). On the other hand, the San Lazzaro deposits were referred to lower shoreface/offshore transition by means of sedimentological features (Baldanza et al., 2014; Bizzarri et al., 2015), and no evidences of deposits related to turbidity currents and/or hyperpycnal flows was found. Thus, the depositional models proposed by Zavala et al. (2012) to account for the richness of plant remains, leaves, charcoal or other very light land-derived materials in distal to deep marine deposits cannot be applied here. As well as the shell lags, these lenses can be interpreted as storm layers: plant remains transported to the sea during intense floods (in mass transport) by small rivers, depending on their size and density, may more or less longer float or quickly settle to the seafloor. As for other bioclasts, woody fragments and even larger branches and 
trunks (Monaco et al., 2011) are remobilized during storm events, and redistributed inside storm layers. The small dimensions of fragments (up to few centimetres, usually $<1 \mathrm{~cm}$ ), the lack of whole leaves, the partially abraded aspect of carpological remains, their concentration inside lenses of very fine sands, surrounded by silty sand-dominated deposits, all indicate discontinuous, wave-induced sedimentation events (tempestites) in a relatively low energy environment. The possibility of reworking of plant material in marine environments was already discussed in Martinetto et al. (2015).

\subsection{The Dunarobba section}

\section{(FIGURE 5 approximately here)}

An updated overview of the stratigraphic information on several sections of the Dunarobba site can be found in Martinetto et al. (2014), and here we concentrate on two types of rich and welldiversified molluscan assemblages from the Dunarobba Forest Section (DF). The first, coming from the silty clays encrusting the trunks, is dominated by extinct hygrophilous land prosobranchs and pulmonates, such as Hydrocena dubrueilliana, Carychium (Saraphia) pachychilum, C. (S.) pseudotetrodon, Negulus villafranchianus, Leiostyla gottschicki, Gastrocopta (Albinula) acuminata fossanensis (= G. (A.) acuminata), Gastrocopta (Vertigopsis) dehmi (= G. (V.) moravica), Eostrobilops aloisii, Staurodon cianfanellianus, Laminifera (Laminiplicata) villafranchiana (= Laminiplica villafranchiana) (Manganelli et al., 1989, 1990; Esu and Girotti, 1991, Esu et al., 1993; Ciangherotti et al., 1998; Manganelli and Giusti, 2000; Manganelli et al., 2008). These species are of high palaeobiogeographical and biochronological interest. Most of them, such as $H$. dubrueilliana, C. pseudotetrodon, N. villafranchianus, G. (V.) dehmi (= G. (V.) moravica), G. (A.) acuminata fossanensis (= G. (A.) acuminata), L. gottschicki, E. aloisii, L. villafranchiana), are in common with the NW Italian assemblages of the late Pliocene (Piacenzian of the marine chronostratigraphy) deposits of Villafranca d'Asti (RDB section) or Ceresole d'Alba and other Pliocene sites (Ciangherotti, 1997; Esu and Ciangherotti, 2004, Ciangherotti et al., 2007), and mostly got extinct during the late Pliocene (Piacenzian)/early Pleistocene (Gelasian) transition. The second assemblage, coming from the sediments around the trunks of the Forest Section (Martinetto et al., 2014), is characterized by aquatic prosobranchs, such as Theodoxus groyanus, Emmericia umbra, Prososthenia paulae, Tournouerina belnensis, Melanopsis affinis, Micromelania (Goniochilus) zitteli, mainly endemic to central Italy and getting extinct in the late early Pleistocene (Ambrosetti et al., 1995b; Ciangherotti et al., 1998; Esu and Girotti, 2001).

Thanks to a high percentage of extinct molluscs of Pliocene character and to the findings of land species common to the late Pliocene molluscan fauna of NW Italy and other European Pliocene sites, it is possible to suggest a late Pliocene age (Piacenzian) for the Dunarobba molluscan fauna, even if a late Pliocene-earliest Pleistocene age (Piacenzian-Gelasian) cannot be excluded. The climatic indications of these molluscs, based on the modern relatives, indicate a warm temperate climate with a high atmospheric humidity, e.g. the genus Eostrobilops lives in East Asia, South of $40^{\circ} \mathrm{N}$, and Negulus in East Africa (Ethiopia) (Esu and Ciangherotti, 2004).

The occurrence of several fruit and seed assemblages in different sections of the Dunarobba site has been recently reported by Martinetto et al. (2014). The most diverse plant assemblage, originating from a sandy bed indicated as DC1b, included 41 species, 8 of which are recognized as HUTEA with a resulting percentage of $20 \%$.

\subsection{The Cava Toppetti II section}

The Cava Toppetti site, a few kilometers south-west of Todi (Fig. 1), was comprehensively investigated during the two last decades, and several sedimentological, stratigraphic, palaeontological and palaeoenvironmental data were collected (Ambrosetti et al., 1995a; Basilici, 1995; Abbazzi et al., 1997; Gliozzi et al., 1997; Pontini, 1997; Leone et al., 2000; Pontini et al., 2002; Martinetto et al., 2014). Due to the presence of two completely different successions, cut through by a main extensional fault, the various records were referred to either Cava Toppetti I, the older succession made up by the Fosso Bianco Unit (FBU), or Cava Toppetti II, the younger 
succession made up by the Ponte Naja Unit (PNU). Both the FBU and PNU (Fig. 2: Ambrosetti et al., 1995a; Basilici, 1995) were well exposed through the quarry fronts in the 1980s-1990s, but later the outcrop was deteriorated by the lack of quarrying activities, the successive backfilling and the slope restoration.

\section{(FIGURE 6 approximately here)}

The about $150 \mathrm{~m}$ thick Cava Toppetti II section pertained to the uppermost PNU; it was composed (Fig. 6) of prevailing clayey-sandy silt deposits (fine-grained sheet flow deposits), with interposed silty clay (palaeosol), planar-concave sandy gravel (stream ribbon channels) and tabular sandy gravel deposits (coarse-grained sheet-flow deposits). A complete sedimentological description and interpretation of PNU deposits can be found in Basilici (1995) and Abbazzi et al. (1997). The palaeoenvironment was reconstructed on a sedimentological basis as the medial and distal portion of an alluvial fan. Several types of sediments locally bear molluscs, whereas fragments of large vertebrates and micromammals were mainly collected inside palaeosols. According to Abbazzi et al. (1997), deposits of Cava Toppetti II section originally overlie the about $300 \mathrm{~m}$ thick lacustrine laminated silty clay deposits of the FBU, attributed to late Pliocene-early Pleistocene by means of magnetostratigraphy (Late Gauss to Early Matuyama Chrons).

At Cava Toppetti II an important biochronological datum is given by the occurrence of the micromammal Apodemus dominans (Argenti, 1999; Sala and Masini, 2007). In the southwestern branch of the Tiberino Basin such occurrence has been recorded also at the Pantalla site, together with a diversified vertebrate assemblage (Gentili et al., 1997; Cherin et al., 2013a, 2013b, 2014a, 2014b). All the vertebrate data support a biochronological framework with Cava Toppetti II and Pantalla referable to the middle-late Villafranchian transition (Coste San Giacomo or Olivola Faunal Units), i.e. to the late Gelasian (Cohen et al., 2013). Recently, Bellucci et al. (2014) provided new data on the Coste San Giacomo faunal assemblage, including also small vertebrates. The age of this deposit, reference locality of the Coste San Giacomo Faunal Unit, has been approximately assessed at 2.1 Ma. The ongoing researches will allow a more detailed comparison of the Cava Toppetti II mammal assemblage to those of Coste San Giacomo and of the other Umbrian localities mentioned above.

The molluscs collected in the alluvial fan deposits of the Cava Toppetti II section (Abbazzi et al., 1997) are characterized by a few extinct freshwater prosobranchs, such as T. groyanus, E. umbra, Choerina tudertis, M. affinis, Prososthenia augusti, P. tassoi, which are endemic to central Italy, and by a few extinct species of land snails, such as Carychium (Carychiella) puisseguri, Carychium (Saraphia) pachychilum, Carychium (S.) pseudotetrodon and Negulus villafranchianus. Among these, only three species are shared with the Dunarobba assemblage, whilst all the species of freshwater prosobranchs were recovered also at Dunarobba. The PNU land molluscan fauna results impoverished in extinct molluscs compared with the Dunarobba one indicating a slightly younger age, that is early early Pleistocene (Gelasian). The lack of most of the thermophilous taxa occurring at Dunarobba, such as the representatives of the genera Hydrocena, Eostrobilops, Staurodon, Laminiplica, suggests a cooler climate during the deposition of the PNU unit in comparison to the Dunarobba Fossil Forest one (Ciangherotti et al., 1998). Furthermore, these taxa are also less exigent in terms of atmospheric humidity.

As for the macroscopic plant remains, the record of the Cava Toppetti II section is rather poor, but an important fruit and seed-bearing deposit (Fig. 7) has been located in the middle part of the section (Fig. 6) and the occurrence of several species had been reported by Martinetto (2001a). As a whole 40 species have been identified, 8 of which are recognized as HUTEA with a resulting percentage of $7 \%$.

\section{(FIGURE 7 approximately here)}

All the data presented above call for a rconfirmation of the chronological position of the Cava Toppetti II section. We know that some recent papers challanged the reliability of several old 
paleomagnetic data, due to some bias on magnetic minerals (e.g. the issue related to the Jaramillo subchron discussed in Muttoni et al., 2014). However, the bulk of data collected in the Tiberino Basin, their correlation with part of the Valdarno Basin sequence, which is also time-calibrated by means of radiometric data (Bertini, 2013), and the magnetic susceptivity-based high-resolution cyclostratigraphy (Pontini et al., 2002; Napoleone et al., 2003, 2004), make the chronologic interpretation of the Cava Toppetti II succession reliable in the light of current knowledge. Thus, on the basis of its palaeontological content and stratigraphic position, the section is thought to be early Pleistocene (Gelasian) in age, younger than the Reunion Event and older than the Olivola Faunal Unit, which is placed at the end of the normal polarity subchron Olduvai (Torre et al., 1996; Napoleone et al., 2003; Bellucci et al., 2014). The sedimentological features suggest a high sedimentation rate ( $>1.3 \mathrm{~mm} / \mathrm{y}$ : Basilici, 1995; Abbazzi et al., 1997), and a time span of about 100 ky to $300 \mathrm{ky}$ is presumed for the whole Cava Toppetti II section, inside the 2.1-1.9 Ma range; (Abbazzi et al., 1997; Leone et al., 2000; Martinetto et al., 2014).

\subsection{Frequency of the HUTEA since $5 \mathrm{Ma}$ and last occurrence of CTEA}

The percentages of species belonging to the HUTEA category in the well-dated reference floras of Italy (Fig. 8, Table 2) show that the Zanclean-Piacenzian assemblages have a higher value (7-31\%), and the HUTEA are constantly present in all the floras that are well dated within this time interval, and also in those tentatively assigned to it (Martinetto et al., 2015; Martinetto, in press). A single HUTEA (Eucommia) occurs in one (Arda-AD3) of the two Gelasian reference assemblages (2\% HUTEA), whereas the other Gelasian assemblage (Casnigo) and all of the Calabrian-Middle Pleistocene ones are devoid of HUTEA. Also the main European carpofloras definitely or possibly dated to the Gelasian-Calabrian would be devoid of HUTEA (Table 2), if not for the occurrence of Eucommia at Tegelen and Schwanheim.

Another late occurrence of two HUTEA species has been reported for a fossil flora of the Colchis area (Kvarbeti, Georgia): Glyptostrobus europaeus and Symplocos casparyi (Symplocos sect. Lodhra). This flora was referred by Chochieva (1975) to the Gurian local stage, which is now correlated to the Calabrian (Shatilova et al., 2014). Biltekin et al. (in press) even suggest the persistence of G. europaeus in the Holocene of the southern Black Sea.

\section{(FIGURE 8 approximately here)}

Our newly recovered Gelasian assemblage of San Lazzaro, with 50\% HUTEA, is an exception at the European scale, but it must be considered that the low number of species may have biased this value. The other Gelasian assemblage available in central Italy, Cava Toppetti II, has 7\% HUTEA and the Piacenzian or Gelasian Dunarobba assemblage has 20\% HUTEA. These floras, similar to other Gelasian-Calabrian ones of Italy (Girotti et al., 2003, Martinetto, 2001a; Martinetto et al., 2015) and Europe (Table 2) are still very rich in CTEA, commonly associated with Parrotia, Pterocarya and Zelkova. By merging the occurrence data of HUTEA (Fig. 9), CTEA (compare Table 1 with data in Martinetto, 2001a, and Martinetto et al., 2015) and TEWA (Martinetto, 2001a; Martinetto et al., 2015) it is apparent that at least 70 plant species disappeared from southern Europe in the time interval between latest Zanclean (3.7 Ma) and early Middle Pleistocene $(0.5 \mathrm{Ma})$.

\section{(FIGURE 9 approximately here)}

\subsection{Ectothermic vertebrate record (amphibians and reptiles)}

The Italian peninsula hosted in the past a few reptile genera that went locally extinct (with a timing different from that of the HUTEA) and now survive in a stripe that extends eastward from the Balkan Peninsula to Indonesia, but still preserves in an exclusive way some amphibians that once had a much larger range. Examples are Agama s.l., Pseudopus, Tomistoma, Vipera (oriental group), among thermophilous reptiles (Delfino, 2002; Kotsakis et al., 2004; Piras et al., 2007; Delfino et al., 2008), and Salamandrina and plethodontid salamanders among the amphibians that are tied to 
humid terrestrial, non lentic or lotic, niches (Delfino, 2002; Venczel and Sanchiz, 2005; Delfino et al., 2006; Delfino and Sala, 2007). Particularly interesting is the case of the fully terrestrial plethodontid salamanders of the genus Hydromantes that have in the Italian biogeographic region the only Palaearctic representatives with their sister taxon living in Korea (Buckley et al., 2010). These lungless salamanders are tied to environments with high environmental humidity that allow gas exchanges through their skin, but the fact that they have interstitial habits could imply the influence of factors that go beyond those that controlled the survival of plants. It should also be mentioned that the last European occurrence of the frog genus Latonia, known since the Oligocene, is the one of Pietrafitta (Delfino, 2002; Rage and Rocek, 2003), a Calabrian site in Central Italy (Martinetto et al., 2014) and that this genus, described on the basis of fossil material and long considered extinct, was recently found alive in Israel (Biton et al., 2013).

\section{Discussion}

Depending on the concepts of "physiological uniformitarianism" (Tiffney and Manchester, 2001) and deterministic late Cenozoic plant extinctions in Europe (Svenning, 2003) we singled out three groups of plant fossil-species occurring in southern Europe: CTEA, HUTEA, TEWA. The CTEA and HUTEA include several species extinct in Europe, belonging to supraspecific plant taxa with a partly shared modern distribution in East Asia. The HUTEA are the descendants of the "exuberant laurophyllous flora" (Kubitzki and Krutzsch, 1996) growing in the warm temperate belt of southern Laurasia during the Eocene. At this time many taxa now distributed in eastern Asia were present in North America and Europe, but later survived only in the first and, partly, in the second continent. For this reason it would be more appropriate to speak about taxa "conserved in East Asia" rather then "of East Asian affinity".

Several taxa that toletared cooler conditions (including many CTEA) tended to occupy a higher latitudinal belt during the Eocene and Early-Middle Miocene, and were able to survive both in eastern Asia and eastern North America, but not in Europe (Tiffney and Manchester, 2001; Wen et al., 2010). In fact, the present Asian-American biogeographic disjunction of several plant taxa (Hamamelis, Liquidambar, Liriodendron, Magnolia, ecc.) "mostly represents relict distributions of a wider distribution in the Tertiary. It is a product of complex processes such as migration/dispersal, extinction, speciation, vicariance, and perhaps also evolutionary convergence and stasis" (Wen et al., 2010).

Phylogenetic studies based on disjuct eastern Asian-eastern North American living plants (e.g. Magnoliaceae: Nie et al, 2008) pointed out that the divergence times mostly date back to EoceneMiocene (Wen et al., 2010). The divergence times of extinct European taxa and their extant eastern Asian sister taxa is poorly understood, even if a few recent studies incorporated fossils in the phylogenies (e.g. Xiang et al., 2006; Denk and Grimm, 2009; Zhang et al., 2013; Fritsch et al., 2015).

Despite this lack of information, the available literature is sufficient to explain why it is convenient to the separate the groups CTEA, HUTEA and TEWA: during the Eocene and/or Early-Middle Miocene, under equable climatic conditions (Wing and Greenwood, 1993; Zachos et al., 2001; Tiffney and Manchester, 2001; Grímsson et al., 2015), a north-south differentiation of the flora (and vegetation) was already present, so that the boreal regions were covered by cool-tolerant taxa (e.g. Fagus, Juglans: Aradhya et al., 2007; Denk and Grimm, 2009), some of which can be classified as CTEA (e.g. Chamaecyparis: Liu et al., 2009), and the middle latitudes were covered by more thermophilous taxa, including many HUTEA and TEWA, not adapted to regular and severe frost (e.g. Cinnamomum, Engelhardia, Mastixia, Ocotea, Sideroxylon, Symplocos sect. Lodhra, Tetraclinis, Toddalia, etc.). However, also several CTEA grew in these warm mid-latitude forests: in fact, even if we indicated the CTEA as a group of cool-tolerant plants, this applies only to the supraspecific taxa, and several CTEA species were probably as thermophilous as the HUTEA (see above the example of Magnolia). This hypothesis is corroborated by the observation that several 
CTEA species display a HUTEA-like pattern of disappearance in Italy (see CTEA2 and CTEA3 in Fig. 9), which could suggest a similar thermophilous attitude.

The analysis of the percentage of HUTEA species in some well-dated early Pliocene to early Pleistocene carpofloras of Italy (excluded those newly analysed here) provided an interesting picture: values above $15 \%$ in the Zanclean, above $7 \%$ in the Piacenzian, $2-0 \%$ percent in the Gelasian and invariably $0 \%$ in the Calabrian (Figs 8, 9). Furthermore, an analysis of the early Pleistocene carpofloras of Europe Table 2) showed that most of them do not contain HUTEA, apart Eucommia and possibly Glyptostrobus and Symplocos sect. Lodhra in the Colchis refugial area (Chochieva, 1975; Shatilova et al., 2014). Thus, our new record of the San Lazzaro section is of particular relevance, because for the first time an assemblage containing a very high percentage $(50 \%)$ of HUTEA is documented in European sediments independently dated to the early Pleistocene. This is in agreement with a previous record (Martinetto, 2001a) of the same species occurring at San Lazzaro (Sinomenium cantalense, Symplocos casparyi, Toddalia rhenana) in the continental sediments of another early Pleistocene site of central Italy, Cava Toppetti II, even if in this second site the percentage of HUTEA is definitely lower $(7 \%)$. The reconsideration of the stratigraphic data, in particular the biochronologic indications of continental molluscs and vertebrates, allows us to confirm a Gelasian age for the Cava Toppetti II section, the flora-bearing layer being most likely deposited between 2.1 and 1.9 Ma. The independent age assignments of the Cava Toppetti II and San Lazzaro sections point to a time-correlation of the warm and humid HUTEA-bearing phase detected in both of them. The combined record of the two sections is fundamental to prove that the three above-mentioned HUTEA species actually survived in central Italy after the Pliocene/Pleistocene boundary, and to rule out the suspect that the occurrence of their carpological remains in the marine San Lazzaro section could be due to the reworking from older (Pliocene) sediments (Martinetto et al., 2015).

Even if most of the HUTEA documented in the Pliocene (Fig. 9) are not yet reported in the early Pleistocene, it may be argued that this is a bias due to the scarcity of records. Indeed, the proved occurrence in the early Pleistocene of such thermophilous and humidity-requiring plants as Symplocos sect. Lodhra and Toddalia suggests the possibility that also other HUTEA would have crossed the Pliocene/Pleistocene boundary. Chiarini et al. (2009) reported fruits of Engelhardia from a poorly dated section that could be of early Pleistocene age. Pollen data suggest the persistence of Engelhardia in central Italy until the Middle Pleistocene (Biltekin et al., in press) and in Spain till to the early Pleistocene (Postigo-Mijarra et al., 2009). These late occurrences are in agreement with the suggestion by Kvaček (2007) that the European Engelhardia is an extinct phylogenetic clade that was more cool-tolerant than the extant Asian species, and possibly it should be excluded from the HUTEA in future analyses.

The possible late occurrence of a few potential HUTEA is also implicit in other South European palynological assemblages (Tsedakis et al., 2006; Postigo-Mijarra et al., 2009; Bertini, 2010; Magri, 2010; Popescu et al., 2010; Orain et al., 2013; Shatilova et al., 2014; Biltekin et al., in press; Combourieu-Nebout et al., 2015), reporting Eucommia, Symplocos and "Taxodiaceae" pollen up to the Calabrian, and in some areas to the Middle Pleistocene (Shatilova et al., 2014; Biltekin et al., in press) or Holocene ("Taxodiaceae": Biltekin et al., in press). However, the identification at genus (for the "Taxodiaceae") or section level (for Symplocos), which is necessary for the assignement to the CTEA or HUTEA, is mostly not provided in such works (except Biltekin et al., in press).

To our knowledge the single macrofossil of a HUTEA in the Middle Pleistocene of Europe is a wood of Amentotaxus sp. (Follieri, 2010) from central Italy, associated to several taxa that later went extinct in Europe (Taxodium, the CTEA Cephalotaxus and Torreya, and the TEWA Ocotea). We cannot exclude that central-southern Italy may have offered a refugial niche that was warm and wet enough to assure the longer survival of a few HUTEA, in contrast to central Europe. In fact pollen data document the persistence of potential HUTEA ("Taxodiaceae") and humidity-requiring CTEA (Carya) till to the Middle Pleistocene in central and southern Italy (Manzi et al., 2011; Magri and Palombo, 2013; Orain et al., 2013; Biltekin et al., in press). However, most of the CTEA have 
the last macrofossil record (Martinetto, 1999, 2001a; Martinetto et al., 2015) in the time span from 1.4 to $0.8 \mathrm{Ma}$ (Fig. 9).

Also a simple comparison of the fossil record and the current distribution of the terrestrial ectothermic vertebrates suggests that the Italian biogeographic region acted as a humid refugium. It is actually tempting to associate the history of plants with that of these animals, whose distribution is clearly related to historical variations of temperature and humidity more directly than that of other vertebrates. However, it seems that despite the possibility of identifying a general common trend there are significant differences that are only partly related to the incompleteness of the fossil records of both groups. Conversely, a particularly intriguing argument is the concomitant persistence in the San Lazzaro section of thermophilous terrestrial plants and unexpected (for the early Pleistocene) thermophilous marine benthic taxa, such as Amphistegina spp. and Persististrombus cf. coronatus (Bizzarri and Baldanza, 2006; Harzhauser and Kronenberg, 2008; Monaco et al., 2011).

It is well known that the Pliocene is characterized by intense climatic oscillations of increasing amplitude, also at the middle latitudes (De Shepper et al., 2013), with cold pulses at 3.7-3.6 Ma, 3.3 Ma (Zanclean/Piacenzian transition) and intense glaciations during late Piacenzian-early Gelasian, at 2.7-2.4 Ma (Zachos et al., 2001; Lisecki and Raymo, 2005; Prescott et al., 2014). The early Pleistocene is characterized by $\sim 40 \mathrm{kyr}$ lower-amplitude glacio-eustatic oscillations (CombourieuNebout et al., 2015), terminating in the mid Pleistocene 'climate revolution' with an abrupt shift to $\sim 100 \mathrm{kyr}$ higher-amplitude oscillations in the late Calabrian, between 0.9 and $0.8 \mathrm{Ma}$ (MIS 23 and MIS 22: Muttoni et al., 2011). This event brought a cooler climate during glacial maxima at the middle latitudes (Ravazzi et al., 2005; Bertini, 2010; Muttoni et al., 2011).

The above-mentioned climatic crises were probably responsible for terrestrial plant extinctions (Svenning, 2003; Eiserhardt et al., 2015). In the Italian record (Martinetto, 1999, 2001a; Martinetto et al., 2015) the HUTEA still show a very high percentage in correspondence of the late Piacenzian "warm blip" (CQ1 assemblage: 31\%), but a marked decrease in the percentage and number of species (Fig. 8) occurs soon after, in the transition from the Piacenzian to the Gelasian. The north Italian plant assemblages formed during the late Piacenzian cooling (Irace et al., 2012) are totally devoid of HUTEA, but this is not the time of their definitive disappearance from Europe. The new record from the independently dated marine section of San Lazzaro and the related continental record from Cava Toppetti II show that at least three species of HUTEA persisted in central Italy in the Gelasian (Sinomenium cantalense, Symplocos casparyi, Toddalia rhenana). Further macrofossil studies in the Calabrian and Middle Pleistocene are needed for a better assessment of the disappearance time of these and other HUTEA species. In parallel, a more precise dating of important fruit and seed bearing sections should be obtained. If the Dunarobba section would be proven to have an early Pleistocene age (Bizzarri et al., 2011; Martinetto et al., 2014), this would imply that at least 8 HUTEA species (20\% of the species in Dunarobba's assemblage DC1b) overcome the Plio/Pleistocene boundary in central Italy (Fig. 9), and the warmest Gelasian peaks still had a flora of definite "Pliocene" character. Actually, the evidences provided by continental molluscs and the fruit and seed assemblages (Fig. 9) suggest a Piacenzian (or transitional Piacenzian-Gelasian) age of the Dunarobba deposits, but also in this case we cannot rule out the persistence of Pliocene taxa in a climatic refugium. In fact, uncertainties in the disappearance time from central Italy of several thermophilous and humid requiring organisms still exist, and further data should be collected. As for plants, particular attention should be addressed to southern Italy, where pollen assemblages (Biltekin et al., in press; Combourieu-Nebout et al., 2015) suggest a longer persistence of thermophilous exotic taxa. However, the lack of palaeocarpological investigations in such an area did not permit a verification of the eventual presence of several HUTEA that do not have a recognizable pollen record (Table 1).

The new data collected and the use of the new categories HUTEA, CTEA and TEWA allow us to provide a description of the massive late Cenozoic plant extinction in southern Europe, which is more detailed and effective than the previous ones. For example, Rodriguez Sanchez and Arroyo 
(2008) recently provided this version of the story: "in the Piacenzian relict genera of the Tethyan flora still coexisted in southern Europe with ancestors of extant Mediterranean taxa. The onset of the Mediterranean climate in the Pliocene, with hot and dry seasons, and the glacial-interglacial cycles of the Quaternary, with recurrent periods of cold and arid conditions, ultimately caused the extinction of many members of the Tethyan Palaeogene flora in Europe and North Africa (Mai, 1989; Svenning, 2003)".

We suggest here a more articulated scenario: during the Miocene the humidity-requiring descendants of both the Palaeotropical ("Tethyan") and Arctotertiary floras coexisted in Europe (Mai, 1989, 1991), and most of them (TEWA excluded) did not develop an adaptation to aridity. A consistent group of plants, namely our HUTEA, also did not adapt to cool climate, whereas in other groups (our CTEA) cool-tolerant forms had been selected in the course of various Cenozoic cool phases (Zachos et al., 2001). The climatic tolerances of the HUTEA, TEWA (e.g. Ficus, Laurus, Liquidambar, Ocotea) and likely thermophilous CTEA species (i.e. CTEA2 in Fig. 9) were probably fixed by a selection under globally equable climates in the Eocene-Miocene time span (Mai, 1989; Wing and Greenwood, 1993; Svenning, 2003; Rodriguez Sanchez and Arroyo, 2008; Manchester et al., 2009; Grímsson et al., 2015), when some HUTEA (Sargentodoxa, Sinomenium) also grew in North America (Manchester et al., 2009), persisting into the Mio/Pliocene transition (Liu and Jacques, 2010).

In southern Europe the HUTEA, TEWA and thermophilous CTEA species still grew together in the same plant communities (see Martinetto and Vassio, 2010; Martinetto et al., 2015) during the Zanclean, Piacenzian and the Gelasian warm peaks, when the climate was favourable for all of them. Later, thanks to their major drought tolerance (Svenning, 2003; Grimm and Denk, 2012; Utescher and Mosbrugger, 2015), the TEWA found some relatively warm refuges in the Mediterranean (Coriaria, Laurus, Liquidambar, Olea, Styrax, Tetraclinis), North Africa (Laurus, Olea, Tetraclinis and, possibly, Morella, Ocotea, Sideroxylon, Visnea) and West Asia (Olea, Sideroxylon). Some TEWA are today conserved in Macaronesia (Morella, Ocotea, Sideroxylon, Visnea) but their arrival there could be as recent as Pleistocene (Kondrasov et al., 2015).

Conversely, the HUTEA did not manage to adapt either to the dry and cool European conditions (Manzi et al., 2011) or to the too dry North African-East Asian ones and survived only in East Asia; just a few of them also survived in wet parts of tropical Africa (e.g. Toddalia) and/or America (e.g. Meliosma subgen. Kingsbouroghia, Sassafras, Saurauia).

As for the chronology of the disappearance, the Italian record would suggest that the HUTEA were constantly present in the Zanclean-Piacenzian flora of southern Europe, had a small retreat at the Zanclean-Piacenzian transition, possibly affecting four species of HUTEA (Fig. 9), and a larger one at the Piacenzian-Gelasian transition (18 species of HUTEA: Fig. 9); three species of HUTEA (Toddalia latisiliquata, T. rhenana, Sinomenium cantalense) seem to disappear at the Gelasian/Calabrian transition, and there is poor evidence in Italy for the few HUTEA which survived in the Calabrian, even if at least two HUTEA species (Glyptostrobus europaeus and Symplocos casparyi) were still present during the Calabrian in the Colchidian refugium (Chochieva, 1975). Engelhardia and Eucommia still occurred in the Calabrian of Italy and Spain (PostigoMijarra et al., 2009; Bertini, 2010; Biltekin et al., in press; Martinetto in press PalB); the last southern European macrofossil record of an HUTEA which is presently known is that of Amentotaxus sp. in the Middle Pleistocene of central Italy (Follieri, 2010).

Similarly to the HUTEA, also the CTEA did not tolerate dry conditions (Svenning, 2003), but a few ones (Carya, Tsuga) still survived in the Middle Pleistocene of central-southern Italy (Magri, 2010), Turkey (Biltekin et al., in press) and the Balkan (Tsedakis et al., 2006; Biltekin et al., in press) and Iberian (Postigo-Mijarra et al., 2009) peninsulas, due to the presence of refugia (CombourieuNebout et al., 2015) which were humid enough, as demonstrated by the continuous presence of the draught-intolerant Fagus until today (Magri, 2008). Parrotia, Pterocarya and Zelkova, which had climatic requirements similar to the CTEA, survived until the present around the Black and Caspian 
seas (Zelkova also in the Mediterranean). Another plant extinct in Europe, Cedrus, has particular requirements and histories (Magri, 2012; Su et al., 2013; Biltekin et al., in press).

As a whole the carpological data, in connection with the abundant pollen data available, testify that in the late Piacenzian-Middle Pleistocene interval at least 70 plant species (Table 1), including HUTEA (Fig. 9), CTEA (Fig. 9, Table 1) and TEWA (Martinetto et al., 2015), disappeared from the fossil record. However, such a disappearance is not readily interpretable as extinction. By comparing our results with those of Bertoldi et al. (1994), Martinetto (1999, 2001a), Martinetto et al. (2007) and Bertini (2010) it is apparent that the rapidly increasing fossil evidence provided by the Italian carpological and pollen records determined a progressive shift of the last occurrence data of several taxa (e.g.: Liriodendron, Magnolia, Sinomenium, Symplocos, Toddalia), and there is still space for further changes based on new fossil evidence. We propose that, based on the present evidence, only the concomitant disappearance events of several species, such as the HUTEA2 + CTEA2 (Fig. 9), should be considered as reliably assessed. These concern only two main phases: The Piacenzian/Gelasian transition (main crisis of the HUTEA2 and CTEA2) and the late Calabrian/Middle Pleistocene (main crisis of the CTEA4, last occurrence of the HUTEA Amentotaxus). The disappearance events of plant macrofossils at the Zanclean/Piacenzian transition (a few HUTEA1) and Gelasian/Calabrian transition (a few HUTEA3 and CTEA3) appear of minor scale, as also confirmed by the relatively continuous pollen records (Tzedakis et al., 2006; PostigoMijarra et al., 2009; Bertini, 2010; Magri, 2010; Orain et al., 2013; Shatilova et al., 2014; Biltekin et al., in press; Combourieu-Nebout et al., 2015). These last events are not univocally interpretable as extinctions, since the taxa which seem to disappear could have become silent for the macrofossil record, though perhaps still present in small relict niches, as suggested by the late occurrence of Eurya cf. stigmosa (CTEA), Glyptostrobys europaeus (HUTEA) and Symplocos casparyi (HUTEA) in the Calabrian of the Colchis refugium (Chochieva, 1975; Mai and Martinetto, 2006) and also of Amentotaxus (HUTEA), Cephalotaxus (CTEA) and Torreya (CTEA) in the Middle Pleistocene of central Italy (Follieri, 2010).

\section{Conclusions}

New data on early Pleistocene fossil fruit and seed assemblages from Italy allowed us to detect several extinct taxa that commonly went unnoticed in pollen analyses. The combined analysis of Pliocene and early Pleistocene occurrence data provided a detailed picture of the reduction of plant diversity in southern Europe. The possible explanation of the causes of plant extinction requires an excursion into deeper times: Several Neogene plants were mainly adapted to grow in thermophilous mesic forests, whose consistent water supply was guaranteed by atmospheric humidity more than groundwater. The climate deterioration of the Plio-Pleistocene cancelled the ecological space of growth of most thermophilous and humidity-requiring taxa. Provided that habitat shift occurred very rarely, most taxa did not manage to adapt to the harsh conditions either from 2.7 to $2.4 \mathrm{Ma}$ or from 1.0 to $0.3 \mathrm{Ma}$, and went extinct. The chance to avoid extinction was not only a question of temperature, but a combination of this with humidity requirements. Southern Europe became extremely dry during the Pleistocene glacials and those plants requiring both higher temperature and consistent water supply had no chance to find a niche to survive, if not adapted to live along rivers (Liquidambar, Parrotia, Platanus, Pterocarya). A few humidity-requiring plants that had already developed an adaptation to cold climate in the Oligocene or Miocene, like Carya, could temporarily survive into the Middle Pleistocene also in the inhospitable Europe, possibly in small, not too dry refugia. A similar niche may have saved Parrotia, but in the south Caspian area.

Our carpological data, in connection to the abundant pollen data available from the literature, testify that the late Zanclean-Middle Pleistocene interval has really been the theatre of a stepwise mass extinction in southern Europe: at least 70 plant species disappeared in two main phases: PiacenzianGelasian transition (main crisis of the HUTEA and CTEA2) and late Calabrian-Middle Pleistocene (main crisis of the CTEA4, last occurrence of the HUTEA Amentotaxus). The disappearance events at the Zanclean-Piacenzian transition (mostly HUTEA1) and Gelasian/Calabrian transition (a few 
HUTEA3 and CTEA3) appear of minor entity and are not univocally interpretable as extinctions. The chronological positions of the two main collective disappearance events coincide with two well-known intervals of major climatic deterioration and support a climatic determinism in the south European extinctions of the investigated plant taxa.

Acknowledgements

We thank G. Basilici for useful information and discussions about the stratigraphy of the Tiberino Basin and for help provided in the field for the positioning of the carpological sample within his Cava Toppetti II section. Thanks to A. Bertini for very useful information on pollen assemblages and for suggestions that improved the whole manuscript, which also profited from the valuable revision carried out by two anonymous referees that we wish to thank. We also thank A. Bruch, T. Denk, G. Grimm, T. Utescher for the useful suggestions on climatic data and for the help in consulting the PALAEOFLORA and ClimGrim databases. I. Gabrielyan and E. Kvavadze provided useful information on the floras of Georgia. Finally we thank M. Dolezych for the confirmation of the unusual Amentotaxus wood record published by the late M. Follieri, who provided us with crucial information on Central Italian floras and whose memory we like to recall to the colleagues reading this paper. Project supported by "Fondi di Ateneo (2012-2013) dell'Università di Torino".

\section{References}

Abbazzi, L., Albianelli, A., Ambrosetti, P., Argenti, P., Basilici, G., Bertini, A., Gentili, S., Masini, F., Napoleone, G., Pontini, M.R., 1997. Paleontological and sedimentological record in Pliocene distal alluvial fan deposits at Cava Toppetti (Todi, Central Italy). Boll. Soc. Paleontol. Ital. 36, 522.

Ambrosetti, P., Basilici, G., Capasso-Barbato, L., Carboni, M.G., Di Stefano, G., Esu, D., Gliozzi, E., Petronio, C., Sardella, R., Squazzini, E., 1995a. Il Pleistocene inferiore nel ramo sud occidentale del bacino tiberino (Umbria): aspetti litostratigrafici e biostratigrafici. Il Quaternario 8, 19-36.

Ambrosetti, P., Basilici, G., Ciangherotti, A.D., Codipietro, G., Corona, E., Esu, D., Girotti, O., Lo Monaco, A., Meneghini, M., Paganelli, A., Romagnoli, M., 1995b. La foresta fossile di Dunarobba (Terni, Umbria, Italia centrale): contesto litostratigrafico, sedimentologico, palinologico, dendrocronologico e paleomalacologico. Il Quaternario 8 (2), 465-508.

Aradhya, M.K., Potter, D., Fangyou, G., Simon, C.J., 2007. Molecular phylogeny of Juglans (Juglandaceae): a biogeographic perspective. Tree Genet. Genomes 3, 363-378.

Argenti, P., 1999. La biocronologia dei Roditori del Plio-Pleistocene dell'Umbria e l'evoluzione del genere Apodemus (Muridae, Rodentia) in Italia). Ph.D. dissertation in Earth Sciences, University of Perugia, $248 \mathrm{pp}$.

Argenti, P., 2004. Plio-Quaternary mammal fossiliferous sites of Umbria (Central Italy). Geol. Romana 37, 67-78.

Baas, J., 1932. Eine Frühdiluviale Flora im Mainzer Becken. Z. Bot. 25, 289-371.

Baldanza, A., Bertinelli, A., Bizzarri, R., Monaco, P., Parisi, G., 2012. Lungo la costa del Mar Tirreno....due milioni di anni fa. In: Peccerillo, A. (Ed.), L'Ignimbrite di Orvieto-Bagnoregio, pp. $135-159$.

Baldanza, A., Bizzarri, R., Famiani, F., Luccioni, I., Pino, P., 2011. Gelasian to Calabrian onland marine record: three case studies in the Mediterranean area. Proceedings of AIQUA Congress: Il Quaternario Italiano - Conoscenze e prospettive (Rome, February 24-25, 2011). Il Quaternario 24, 17-19.

Baldanza, A., Bizzarri, R., Famiani, F., Pasini, G., Garassino, A., De Angeli, A., 2014. The early Pleistocene shallow marine decapod crustaceans community from Fabro Scalo (western Umbria, central Italy): taxonomic inferences and palaeoenvironmental reconstruction. Neues Jahrb. Geol. P.A. 271 (3), 261-283.

Basilici, G., 1995. Sedimentologia della parte distale di un conoide alluvionale del Pliocene superiore (Bacino Tiberino, Umbria). Il Quaternario 8, 37-52. 
Basilici, G., 1997. Sedimentary facies in an extensional and deep - lacustrine depositional system: the Pliocene Tiberino Basin, Central Italy. Sediment. Geol. 109, 73-94.

Basilici, G., 2000a. Pliocene lacustrine deposits of the Tiberino Basin (Umbria, central Italy). In: Gierlowski-Kordesch, E.H., Kelts, K.R. (Eds.), Lake basins through space and time. AAPG Studies in Geology, vol. 46, pp. 505-514.

Basilici, G., 2000b. Floodplain lake deposits on an early Pleistocene alluvial plain (Tiberino Basin, Central Italy). In: Gierlowski-Kordesch, E.H., Kelts, K.R. (Eds.), Lake basins through space and time. AAPG Studies in Geology, vol. 46, pp. 535-542.

Basilici, G., Martinetto, E., Pavia, G., Violanti, D., 1997. Paleoenvironmental evolution in the Pliocene marine-coastal succession of Val Chiusella (Ivrea, NW Italy). Boll. Soc. Paleontol. Ital. 36 (1-2), 23-52.

Bellucci, L., Bona, F., Corrado, P., Magri, D., Mazzini, I., Parenti, F., Scardia, G., Sardella, R., 2014. Evidence of late Gelasian dispersal of African fauna at Coste San Giacomo (Anagni Basin, central Italy): Early Pleistocene environments and the background of early human occupation in Europe. Quat. Sci. Rev. 96, 72-85.

Bertini, A., 2010. Pliocene to Pleistocene palynoflora and vegetation in Italy: State of the art. Quat. Int. 225, 5-24.

Bertini, A., 2013. Climate and vegetation in the Upper Valdarno basin (central Italy) as a response to Northern Hemisphere insolation forcing and regional tectonics in the late Pliocene-early Pleistocene. Ital. J. Geosci. 132 (1), 137-148.

Bertini, A., Martinetto, E., 2011. Reconstruction of vegetation transects for the Messinian / Piacenzian of Italy by means of comparative analysis of pollen, leaf and carpological records. Palaeogeogr. Palaeoclimatol. Palaeoecol. 304, 230-246.

Bertoldi, R., Martinetto E., 1995. Ricerche paleobotaniche (palinologiche e paleocarpologiche) sulla successione "villafranchiana" del Rio Ca' Viettone. Il Quaternario 8 (2), 403-422.

Bertoldi, R., Binotti, A., Castello F., 1994. Reevesia and Itea in the pollen flora of the Upper Neogene continental deposit at Sarzana (lower Magra valley, Northern Italy). Rev. Palaeobot. Palynol. 80 (1-2), 159-172.

Biltekin, D., Popescu S.M., Suc, J.P., Quézel, P., Jiménez-Moreno, G., Yavuz, N., Çağatay, M.N., in press. Anatolia: a long-time plant refuge area documented by pollen records over the last 23 Million years. Rev. Palaeobot. Palynol.

Biton, R., Geffen, E., Vences, M., Cohen, O., Bailon, S., Rabinovich, R., Malka, Y., Oron, T., Boistel, R., Brumfeld, V., Gafny, S., 2013. The rediscovered Hula painted frog is a living fossil. Nat. Commun. 4, 1959. DOI: 10.1038/ncomms2959

Bizzarri, R., Baldanza, A., 2006. On the meaning of the Amphistegina levels in the Plio Pleistocene of the Orvieto area (Central Italy). In: Coccioni, R., Marsili A. (Eds.), Proceedings of the Second and Third Italian Meetings on Environmental Micropaleontology. Grzybowski Foundation Spec. Publ., vol. 11, pp. 13-20.

Bizzarri, R., Baldanza, A., 2009. Plio-Pleistocene deltaic deposits in the Città della Pieve area (western Umbria, central Italy): facies analysis and inferred relations with the South Chiana Valley fluvial deposits. Il Quaternario 22 (2), 127-138.

Bizzarri, R., Albianelli, A., Argenti, P. Baldanza, A., Colacicchi, R., Napoleone, G., 2011. The latest continental filling of Valle Umbra (Tiber Basin, central Italy) dated to one million years ago by magnetostratigraphy. Il Quaternario 24 (1), 51-65.

Bizzarri, R., Rosso, A., Famiani, F., Baldanza, A., 2015. Lunulite bryozoans from Early Pleistocene deposits of SW Umbria (Italy): sedimentological and paleoecological inferences. Facies (available on line), doi: 10.1007/s10347-014-0420-6.

Bown, P.R., Young, J.R., 1998. Techniques. In: Bown, P.R. (Ed.), Nannofossil biostratigraphy. Kluwer Academic Publishing, The Netherlands, pp. 17-28.

Bruch, A., Zhilin, S.G., 2006. Early Miocene climate of Central Eurasia - Evidence from Aquitanian floras of Kazakhstan. Palaeogeogr. Palaeoclimatol. Palaeoecol. 248 (1-2), 32-48. 
Bruch, A.A., Utescher, T., Mosbrugger, V., 2011. Precipitation patterns in the Miocene of Central Europe and the development of continentality. Palaeogeogr. Palaeoclimatol. Palaeoecol. 304, 202211.

Buckley, D., Wake, M.H., Wake, D.B., 2010. Comparative skull osteology of Karsenia koreana (Amphibia, Caudata, Plethodontidae). J. Morphol. 271, 533-558.

Buzek, C., Kvacek, Z., Holy, F., 1985. Late Pliocene palaeoenvironment and correlation of the Vildstejin floristic complex within Central Europe. Rozpravy Ceskoslovenske Akademie Ved 95 (7), 1-72.

Cavallo, P., Martinetto, E., 2001. Flore carpologiche del Pliocene di Castelletto Cervo (Biella). Boll. Mus. Reg. Sci. Nat. Torino 18 (2), 277-343.

Chiarini, E., Giardini, M., Mattei, M., Porreca, M., Papasodaro, F., Sadori, L., 2009. PlioQuaternary geological evolution of the high Salto river valley (central Italy): the Marano de' Marsi unit. Il Quaternario 22, 325-344.

Cherin, M., Bertè, D.F., Rook, L., Sardella, R., 2013a. Canis etruscus (Canidae, Mammalia) and its role in the faunal assemblage from Pantalla (Perugia, central Italy): comparison with the Late Villafranchian large carnivore guild of Italy. Boll. Soc. Paleontol. Ital. 52 (1), 11-18.

Cherin, M., Iurino, D.A., Sardella, R., 2013b. New well-preserved material of Lynx issiodorensis valdarnensis (Felidae, Mammalia) from the Early Pleistocene of Pantalla (central Italy). Boll. Soc. Paleontol. Ital. 52 (2), 103-111.

Cherin, M., Bertè, D.F., Rook, L., Sardella, R., 2014a. Re-defining Canis etruscus (Canidae, Mammalia): a new look into the evolutionary history of Early Pleistocene dogs resulting from the outstanding fossil record from Pantalla (Italy). J. Mamm. Evol. 21, 95-110.

Cherin, M., Iurino, D.A., Sardella, R., Rook, L., 2014b. Acinonyx pardinensis (Carnivora, Felidae) from the Early Pleistocene of Pantalla (Italy): predatory behavior and ecological role of the giant Plio-Pleistocene cheetah. Quat. Sci. Rev. 87, 82-97.

Chochieva, K.I. 1965. The flora and vegetation of the Chaudian horizon of Guria. "Metsniereba" Publ. H., Tbilisi (in Russian).

Chochieva, K.I., 1975. The Khvarbetian fossil forest. "Metsniereba” Publ. H., Tbilisi (in Russian). Ciangherotti, A.D., 1997. Paleoecologic and biostratigraphic analysis of the Middle Pliocene land molluscan faunas from the RDB quarry (Villafrancad'Asti, Piedmont, North-West Italy). Boll. Soc. Paleontol. Ital. 36, 293-301.

Ciangherotti, A.D., Esu, D., Girotti, O., 1998. Review of the history of the Late Neogene-Early Quaternary non-marine molluscs of Italy. Mededelingen Nederlandse Instituut Toegepaste Geowetenschappen TNO 60, 491-498.

Ciangherotti, A., Esu, D., Martinetto, E., Giuntelli, P., 2007. The remarkable Middle Pliocene nonmarine mollusc record from Ceresole d'Alba, Piedmont, north-west Italy: Biochronology, palaeobiogeography and palaeoecology supported by fossil plants. Geobios 40, 573-587.

Cohen, K.M., Finney, S.C., Gibbard, P.L., Fan, J.-X., 2013. The ICS International Chronostratigraphic Chart. Episodes 36, 199-204.

Combourieu-Nebout, N., Bertini, A., Russo-Ermolli, E., Peyron, O., Klotz, S., Montade, V., Fauquette, S., Allen, J., Fusco, F., Goring, S., Huntley, B., Joannin, S., Lebreton, V., Magri, D., Martinetto, E., Orain, R., Sadori, L., 2015. Climate Changes in central Mediterranean and Italian vegetation dynamics since the Pliocene. Rev. Palaeobot. Palynol. DOI: 10.1016/j.revpalbo.2015.03.001

Delfino, M., 2002. Erpetofaune italiane del Neogene e del Quaternario. Ph.D. dissertation in Palaeontology, University of Modena and Reggio Emilia, 382 pp.

Delfino, M., Sala, B., 2007. Late Pliocene Albanerpetontid (Lissamphibia) from Italy. J. Vertebr. Paleontol. 27 (3), 716-719.

Delfino, M., Razzetti, E., Salvidio, S., 2005. European plethodontids: palaeontological data and biogeographical considerations. Atti Museo Civico Storia Naturale "G. Doria" Genova, 97, 45-58. 
Delfino, M., Kotsakis, T., Arca, M., Tuveri, C., Pitruzzella, G., Rook, L., 2008. Agamid lizards from the Plio-Pleistocene of Sardinia (Italy) and an overview of the European fossil record of the family. Geodiversitas 30 (3), 641-656.

Denk, T., Grimm, G.W., 2009. The biogeographic history of beech trees. Rev. Palaeobot. Palynol. $158,83-100$.

De Schepper, S., Groeneveld, J., Naafs, B.D.A., Van Renterghem, C., Jan Hennissen, Head, M. J., Louwye, S., Fabian, K., 2013. Northern Hemisphere Glaciation during the Globally Warm Early Late Pliocene. PLOS one, 1-15. PLoS ONE 8(12): e81508. doi:10.1371/journal.pone.0081508

Eiserhardt, W.L., Borchsenius, F., Plum, C.M., Ordonez, A., Svenning, J.-C., 2015. Climate-driven extinctions shape the phylogenetic structure of temperate tree floras. Ecology Letters, early online, doi: 10.1111/ele.12409

Engler, A., 1879-1882. Versuch einer Entwicklungsgeschichte der Pflanzenwelt seit der Tertiaerperiode, Vols 1-2. Engelmann, Leizpig.

Esu, D., Ciangherotti, A., 2004. Palaeoecologic and palaeobiogeographic character of Middle Pliocene non-marine molluscfaunas from North-western Italy. Riv. It. Paleont. Strat. 110, 517-530. Esu, D., Girotti, O., 1991. Late Pliocene and Pleistocene assemblages of continental molluscs in Italy. A survey. Il Quaternario 4, 137-150.

Esu, D., Girotti, O., 2001. The genus Prososthenia Neumayr in Italy (Gastropoda: Prosobranchia: Hydrobiidae). Boll. Soc. Paleontol. Ital. 40, 179-184.

Esu, D., Girotti, O., Kotsakis, T., 1993. Palaeobiogeographical observations on Villafranchian continental molluscs of Italy. Scripta Geologica, spec. vol. 2, pp. 101-119.

Fang, J., Yoda, K., 1989. Climate and vegetation in China II. Distribution of main vegetation types and thermal climate. Ecol. Res. 4, 71-83.

Fang, J., Wang, Z., Tang, Z., 2009. Atlas of Woody Plants in China. Volumes 1 to 3 and index. Higher Education Press, Beijing.

Fang, J., Wang, Z., Tang, Z., 2011. Atlas of Woody Plants in China, distribution and climate, volume 1. Springer, $1972 \mathrm{pp}$.

Faranda, C., Gliozzi, E., 2008. The ostracod fauna of the Plio-Pleistocene Monte Mario succession (Roma Italy). Boll. Soc. Paleontol. Ital.47, 215-267.

Follieri, M. 2010. Conifer extinction in Quaternary Italian records. Quat. Int. 225 (1), 37-43.

Fritsch, P.W., Manchester, S. R., Stone, R.D., Cruz, B.C., Almeda, F., 2015. Northern Hemisphere origins of the amphi-Pacific tropical plant family Symplocaceae. J. Biogeogr. 42, 891-901. Gavin, D.G., Fitzpatrick, M., Gugger, P.F., et al. 2014. Climate refugia: joint inference from fossil records, species distribution models, and phylogeography. New Phytologist 204 (1), 37-54.

Geissert, F., Gregor, H.J., Mai, D.H., 1990. Die "Saugbaggerflora" eine Frücht- und Samenflora aus dem Grenzbereich Miozän - Pliozän von Sessenheim im Elsass (Frankreich). Documenta naturae 57, 1-208.

Gentili, S., Ambrosetti, P., Argenti, P., 1997. Large carnivore and other mammal fossils from the Early Pleistocene alluvial plain of the Tiberino Basin (Pantalla, central Italy). Preliminary reports. Boll. Soc. Paleontol. Ital. 36, 231-238.

Ghiotto, P., 2010. La carpoflora del bacino lacustre villafranchiano di Steggio (Treviso, Prealpi orientali). Boll. Mus. Reg. Sci. Nat. Torino 27, 3-99.

Gibbard, P.H., Head, M.J., Walker, M.J.C. \& The Subcommission On Quaternary Stratigraphy, 2010. Formal ratification of the Quaternary System/Period and the Pleistocene Series/Epoch with a base at 2.58 Ma. J. Quat. Sci. 25 (2), 96-102.

Girotti, O., Capasso Barbato, L., Esu, D., Gliozzi, E., Kotsakis, A., Martinetto, E., Petronio, C., Sardella, R., Squazzini, E., 2003. The section of Torre Picchio (Terni, Umbria, Central Italy): a Villafranchian site rich in Mammals, Molluscs, Ostracods and Plants. Riv. Ital. Paleont. Strat. 109 (1), 77-98.

Gliozzi, E., Abbazzi, L., Argenti, P., Azzaroli, A., Caloi, L., Capasso-Barbato, L., Di Stefano, G., Ficcarelli, G., Kotsakis, T., Masini, F., Mazza, P., Mezzabotta, C., Palombo, M.R., Petronio, C., 
Rook, L., Sala, B., Sardella, R., Torre, D., Zanalda, E., 1997. Biochronology of selected Mammals, Mollusc and Ostracods from the Middle Pliocene to the Late Pleistocene in Italy. The state of the art. Riv. It. Paleont. Strat. 103, 368-388.

Goring, S., Lacourse, T., Pellatt, M.G., Mathewes, R.W., 2013. Pollen assemblage richness does not reflect regional plant species richness: a cautionary tale. J. Ecol. 101, 1137-1145.

Gregor, H.J., 1979. Systematics, Biostratigraphy and Paleoecology of the Genus Toddalia Jussieu (Rutaceae) in the European Tertiary. Rev. Palaeobot. Palynol. 28, 311-363.

Gregor, H.J., 1990. Contribution to the Late Neogene and Early Quaternary floral history of the Mediterranean. Rev. Paleobot. Palynol. 62, 309-338.

Grichuk, V. P., 1997. Late Cenozoic changes of flora in extra-tropical Eurasia in the light of paleomagnetic stratigraphy. In: Van Couvering, J. A. (ed.). The Pleistocene Boundary and the Beginning of the Quaternary. Cambridge University Press, Cambridge, pp. 104-113.

Grimm, G.W., Denk, T., 2012. Reliability and resolution of the coexistence approach - a revalidation using modern-day data. Rev. Palaeobot. Palynol. 172, 33-47.

Grímsson, F., Zetter, R., Grimm, G.W., Pedersen, G.K., Pedersen, A.K., Denk T., 2015. Fagaceae pollen from the early Cenozoic of West Greenland: revisiting Engler's and Chaney's Arcto-Tertiary hypotheses. Plant Syst. Evol. 301 (2), 809-832.

Günther, T., Gregor H. J., 1990. Computer-Analyse mitteleuropäischer Frucht- und Samenfloren Europas, Band 2. Documenta Naturae 50 (2), 1-159.

Harzhauser, M., Kronenberg, G.C., 2008. A note on Strombus coronatus Defrance, 1827 and Strombus coronatus Röding, 1798 (Molluscs: Gastropoda). Veliger 50 (2), 120-128.

Hattori, T., Nakanishi, S., 1985. On the distribution limits of the lucidophyllous forest in the Japanese Archipelago. Bot. Mag. Tokyo 98: 317-333.

Hou, H.Y., 1983. Vegetation of China with reference to its geographical distribution. Annals of the Missouri Botanical Garden 70, 509-548.

Jacques, F. M. B., Shi, G., Wang, W. M., 2013. Neogene zonal vegetation of China and the evolution of the winter monsoon. B. Geosci. 88, 175-193.

Kira, T., 1991. Forest Ecosystems of East and Southeast Asia in a Global Perspective. Ecol. Res. 6, 185-200.

Kirchheimer, F., 1957. Die Laubgewächse der Braunkohlenzeit mit einem kritischen Katalog ihrer Früchte und Samen. W. Knapp Verlag, Halle/Saale, 783 pp.

Kotsakis, T., Delfino, M., Piras, P., 2004. Italian Cenozoic crocodilians: taxa, timing and biogeographic implications. Paleogeogr. Paleoclimatol. Paleoecol. 210, 67-87.

Kovar-Eder, J., Jechorek, H., Kvaček, Z., Parashiv, V., 2008, The Integrated Plant Record: An essential tool for reconstructing Neogene zonal vegetation in Europe. Palaios 23, 97-111.

Kvaček, Z., 2007. Do extant nearest relatives of thermophile European Tertiary elements reliably reflect climatic signal? Palaeog. Palaeoclim. Palaeoecol. 253, 32-40.

Irace, A., Monegato, G., Tema, E., Martinetto, E., Pini, R., Gianolla, D., Bellino, L., 2012. The Pliocene-Pleistocene transition in Southern Piedmont: new data from the Alessandria Basin. INQUA-SEQS 2012: Sassari, Italy, pp. 41-42.

Leone, G., Bonadonna, F., Zanchetta, G., 2000. Stable isotope record in mollusca and pedogenic carbonate from Late Pliocene soils of Central Italy. Palaeogeogr. Palaeoclimatol. Palaeoecol. 163, $115-131$.

Lisiecki L.E., Raymo M.E., 2005. A Pliocene-Pleistocene stack of 57 globally distributed benthic delta O-18 records. Paleoceanogr. 20, 1003.

Liu, Y.-S. (C.), Jacques, F.M.B., 2010. Sinomenium macrocarpum sp. nov. (Menispermaceae) from the Miocene-Pliocene transition of Gray, northeast Tennessee, USA. Rev. Palaeobot. Palynol. 159, $112-122$.

Liu, Y.-S. (C.), Mohr, B.A.R., Basinger, J.F., 2009. Historical biogeography of the genus Chamaecyparis (Cupressaceae, Coniferales) based on its fossil record. Palaeobiodiv. Palaeoenvir. 89, 203-209. 
Liu, Y.-S. (C.), Utescher, T., Zhou, Z., Sun, B., 2011. The evolution of Miocene climates in North China: Preliminary results of quantitative reconstructions from plant fossil records. Palaeogeogr. Palaeoclimatol. Palaeoecol. 304, 308-317.

Lowe, D.R., 1982. Sediment gravity flows II. Depositional models with special reference to the deposits of high-density turbidity currents. J. Sedim. Petrol. 52 (1), 279-297.

Kondraskov, P., Schütz, N., Schüßler, C., de Sequeira, M.M., Guerra, A.S., Caujapé-Castells, J., Jaén-Molina, R., Marrero-Rodríguez, Á., Koch, M.A., Linder, P., Kovar-Eder, J., Thiv, M., 2015. Biogeography of Mediterranean Hotspot Biodiversity: Re-Evaluating the 'Tertiary Relict' Hypothesis of Macaronesian Laurel Forests. PloS ONE 10(7): e0132091(1-17).

Magri, D., 2008. Patterns of post-glacial spread and the extent of glacial refugia of European beech (Fagus sylvatica). J. Biogeogr. 35, 450-463.

Magri, D., 2010. Persistence of tree taxa in Europe and Quaternary climate changes. Quat. Int. 219, $145-151$.

Magri, D., 2012. Quaternary history of Cedrus in southern Europe. Ann. Bot. (Roma) 2012 (2), 5766.

Magri, D., Palombo, M.R., 2013. Early to Middle Pleistocene dynamics of plant and mammal communities in South West Europe. Quat. Int. 288, 63-72.

Mai, D.H., 1964. Die Mastixioideen-Floren im Tertiär der Oberlausitz. Paläont. Abh. B 2 (1), 1192.

Mai, D.H., 1970. Subtropische Elemente im europäischen Tertiär I. Die Gattungen Gironniera, Sarcococca, Illicium, Evodia, Ilex, Mastixia, Symplocos und Rehderodendron. - Paläont. Abh. B, 3 (3-4), 441-503.

Mai, D.H., 1975. Beiträge zur Bestimmung und Nomenklatur fossiler Magnolien. Feddes Repert., 86 (9-10): 559-578.

Mai, D.H., 1989. Development and regional differentiation of the European vegetation during the Tertiary. Plant Syst. Evol. 162, 79-91.

Mai, D.H., 1991. Palaeofloristic changes in Europe and the confirmation of the ArctotertiaryPalaeotropical geofloral concept. Rev. Palaeobot. Palynol. 68, 29-36.

Mai, D.H., 1995a. Tertiäre Vegetationsgeschichte Europas. Gustav Fischer, Jena, 691 pp.

Mai, D.H., 1995b. Paleocarpological investigations in the Villafranchian (Pliocene) of Italy. Boll. Mus. Reg. Sci. Nat. Torino 13 (2), 407-437.

Mai, D.H., Martinetto, E., 2006. A reconsideration of the diversity of Symplocos in the European Neogene on the basis of fruit morphology. Rev. Palaeobot. Palynol.140, 1-26.

Mai, D.H., Velitzelos, E., 2007. The fossil flora of Kallithea (Rhodes, Greece) at the Pliocene/Pleistocene boundary. Palaeontographica Abt. B 277, 75-99.

Mai, D.H., Walther, H., 1988. Die pliozänen Floren von Thüringen Deutsche Demokratische Republik. Quartärpaläont. 7, 55-297.

Manchester, S.R, Chen, Z.D., Lu, A.M., Uemura, K., 2009. Eastern Asian endemic seed plant genera and their paleogeographic history throughout the Northern Hemisphere. J. Syst. Evol. 47 (1), $1-42$.

Manganelli, G., Giusti, F., 2000. The gastrocoptids of the Fossil Forest of Dunarobba (central Italy) and a preliminary revision of the European Tertiary nominal species of Albinula and Vertigopsis (Gastropoda Pulmonata: Gastrocoptidae). Boll. Soc. Paleontol. Ital. 39 (1), 55-82.

Manganelli, G., Delle Cave, L., Giusti, F., 1989. Notulae Malacologicae, XLII. Strobilopsidae (Gastropoda, Pulmonata), a family new to the Villafranchian land snail fauna of Apenninic Italy. Basteria 53, 3-13.

Manganelli, G., Giusti, F., Delle Cave, L., 1990. Notulae Malacologicae, XLVIII. Lauriinae (Gastropoda: Pulmonata, Orculidae/Pupillidae) from the Villafranchian of the peninsular Italy. Basteria 54, 87-103. 
Manganelli, G., Benocci, A., Esu, D., Giusti, F., 2008. Staurodon cianfanellianus n. sp. (Gastropoda Pulmonata), a new nesopupinevertiginid snail from the Middle-Late Pliocene Fossil Forest of Dunarobba (central Italy). Boll. Soc. Paleontol. Ital. 47, 211-214.

Manzi, G., Magri, D., Palombo, M.R., 2011. Early-Middle Pleistocene environmental changes and human evolution in the Italian peninsula. Quat. Sci. Rev. 30, 1420-1438.

Martinetto, E., 1994. Analisi paleocarpologica dei depositi continentali pliocenici della Stura di Lanzo. Boll. Mus. Reg. Sci. Nat. Torino 12 (1), 137-172.

Martinetto, E., 1995. Significato cronologico e paleoambientale dei macrofossili vegetali nell'inquadramento stratigrafico del "Villafranchiano" di alcuni settori del Piemonte (Italia NW). Ph.D. Thesis, University of Turin, Italy.

Martinetto, E., 1998. East Asian elements in the Plio-Pleistocene floras of Italy. In: Aoluo, Z., Sugong, W. (Eds.), Proc. Int. Symp. Floristic Charact. Diversity East Asian Plants. Springer-Verlag, pp. 71-87.

Martinetto, E., 1999. Chronological framing of Pliocene to Early Pleistocene plant macrofossil assemblages from northern Italy. Acta Palaeobot. Suppl. 2, 503-511.

Martinetto, E., 2001a. The role of central Italy as a centre of refuge for thermophilous plants in the late Cenozoic. Acta Palaeobot. 41 (2), 299-319.

Martinetto, E., 2001b. Studies on some exotic elements of the Pliocene floras of Italy. Palaeont. Abt. B 259, 149-166.

Martinetto, E., 2003. Leaves of terrestrial plants from the shallow marine and transitional Pliocene deposits of Asti (Piedmont, NW Italy). Boll. Soc. Paleontol. Ital. 42 (1-2), 75-11.

Martinetto, E., 2009. Palaeoenvironmental significance of plant macrofossils from the Piànico Formation, Middle Pleistocene of Lombardy, North Italy. Quat. Int. 204, 20-30.

Martinetto, E., Scardia, G., Varrone, D., 2007. Magnetobiostratigraphy of the Stura di Lanzo fossil forest succession (Piedmont, Italy). Riv. Ital. Paleont. Strat. 113 (1), 109-125.

Martinetto, E., Bertini, A., Basilici, G., Baldanza, A., Bizzarri, R., Cherin, M., Gentili, S., Pontini, M.R., 2014. The plant record of the Dunarobba and Pietrafitta sites in the Plio-Pleistocene palaeoenvironmental context of central Italy. Alp. Med. Quat. 27 (1), 29-72.

Martinetto, E., Monegato, G., Irace, A., Vaiani, S.C., Vassio, E., 2015. Pliocene and Early Pleistocene carpological records of terrestrial plants from the southern border of the Po Plain (northern Italy). Rev. Palaeobot. Palynol., doi:10.1016/j.revpalbo.2014.10.007

Martinetto, E., in press. Challenges to the monographic investigation of the Pliocene and Early Pleistocene carpofloras of Italy. Palaeontographica Abt. B.

McNeill, J., Barrie, F.R., Buck, W.R., Demoulin, V., Greuter, W., Hawksworth, D.L., Herendeen, P.S., Knapp, S., Marhold, K., Prado, J., Prud'homme van Reine, W.F., Smith, G.F., Wiersema, J.H., Turland, N.J. (eds. \& comps.), 2012. International Code of Nomenclature for algae, fungi, and plants (Melbourne Code), adopted by the Eighteenth International Botanical Congress Melbourne, Australia, July 2011. Koeltz Scientific Books, Königstein, 240 pp.

Momohara, A., 2015. Stages of major floral change in Japan based on macrofossil evidence and their connection to climate and geomorphological changes since the Pliocene. Quat. Int., doi:10.1016/j.quaint.2015.03.008.

Monaco, P., Famiani, F., Bizzarri, R., Baldanza, A., 2011. First documentation of wood borings (Teredolites and insect larvae) in isolated clasts of Early Pleistocene lower shoreface deposits (Orvieto area, central Italy). Boll. Soc. Paleontol. Ital. 50 (1), 55-63.

Muttoni, G., Scardia, G., Kent, D.V., Morsiani, E., Tremolada, F., Cremaschi, M., Peretto, C., 2011. First dated human occupation of Italy at $\sim 0.85 \mathrm{Ma}$ during the late Early Pleistocene climate transition. Earth Planet. Sc. Lett. 307, 241-252.

Muttoni, G., Kent, D.V., Scardia, G., Monesi, E., 2014. Migration of hominins with megaherbivores into Europe via the Danube-Po gateway in the late Matuyama climate revolution. Riv. It. Paleont. Strat. $120(3), 351-365$. 
Napoleone, G., Albianelli, A., Azzaroli, A., Bertini, A., Magi, M., Mazzini, M., 2003. Calibration of the Upper Valdarno Basin to the Plio-Pleistocene for correlating the Apennine continental sequences. Il Quaternario 16 (1Bis), 131-166.

Napoleone, G., Albianelli, A., Fischer, A.G., 2004. Magnetic susceptibility cycles in Upper Pliocene lacustrine deposits of the Northern Apennines, Italy. In: Cyclostratigraphy: Approaches and Case Histories. SEPM Spec. Publ., vol. 81, pp. 263-274.

Nemec, W., Steel, R.J., 1984. Alluvial and coastal conglomerates: their significant features and some comments on gravelly mass - flow deposit. In: Koster, E.H., Steel, R.J. (Eds.), Sedimentology of gravels and conglomerates. CSPG Mem., vol. 10, pp. 1-31.

Orain, R., Lebreton, V., Russo Ermolli, E., Combourieu-Nebout, N., Sémah, A.M., 2013. Carya as marker for tree refuges in southern Italy (Boiano basin) at the Middle Pleistocene. Palaeogeogr. Palaeoclimatol. Palaeoecol. 369, 295-302.

Petronio, C., Argenti, P., Caloi, C., Esu, D., Girotti, O., Sardella, R., 2003. Updating Villafranchian mollusc and mammal faunas in Umbria and Latium (Central Italy). Geol. Romana 36, 369-387.

Piras, P., Delfino, M., Del Favero, L., Kotsakis, T., 2007. Phylogenetic position of the crocodylian Megadontosuchus arduini (de Zigno, 1880) and tomistomine palaeobiogeography. Acta Pal. Pol. 52 (2), 315-328.

Pontini, M.R., 1997. Analisi palinologica e interpretazione paleo climatica dei depositi continentali del Bacino Tiberino (Umbria, Italia). Ph.D. dissertation in Palaeontology, University of Perugia, $134 \mathrm{p}$.

Pontini, M.R., Albianelli, A., Basilici, G., Bertini, A., Napoleone, G., 2002. Palynology and magnetostratigraphy of the Middle - Late Pliocene lacustrine sequence in the Tiberino basin (central Italy). Boll. Soc. Geol. It., Vol. Spec. 1 (2), pp. 467-472.

Popescu, S.M., Biltekin, D., Winter, H., Suc, J.P., Melinte-Dobrinescu, M.C., Klotz, S., Combourieu-Nebout, N., Rabineau, M., Clauzon, G., Deaconu, F., 2010. Pliocene and Lower Pleistocene vegetation and climate changes at the European scale: Long pollen records and climatostratigraphy. Quat. Int. 219, 152-167.

Popova, S., Utescher, T., Gromyko, D.V., Bruch, A.A., Mosbrugger, V., 2012. Palaeoclimate evolution in the Cenozoic of Siberia - evidence from fruit and seed floras. Turk. J. Earth Sci. 21, 315-334.

Postigo-Mijarra, J.M., Barrón, E., Manzaneque, F., Morla, C., 2009. Floristic changes in the Iberian Peninsula and Balearic Islands during the Cenozoic. J. Biogeogr. 36 (11), 2025-2043.

Prescott, C.L., Haywood, A. M., Dolan, A.M., Hunter, S.J., Pope, J.O, Pickering, S.J., 2014. Assessing orbitally-forced interglacial climate variability during the mid-Pliocene Warm Period. Earth Planet. Sci. Lett. 400, 261-271.

Qian, H., Wang, S., He, J.S., Zhang, J., Wang, L., Wang, X., Guo, K., 2006. Phytogeographical analysis of seed plant genera in China. Ann. Bot-London 98, 1073-1084

Raffi, I., 2002. Revision of the early - middle Pleistocene calcareous nannofossil biochronology (1.75-0.85 Ma). Mar. Micropaleontol. 45, 25-55.

Rage, J.C., Rocek, Z., 2003. Evolution of anuran assemblages in the Tertiary and Quaternary of Europe, in the context of palaeoclimate and palaeogeography. Amphib. Reptil. 24, 133-250.

Ravazzi, C., Pini, R., Breda, M., Martinetto, E., Mattoni, G., Chiesa, S., Confortini, F., Egli, R., 2005. The lacustrine deposits of Fornaci di Ranica (late Early Pleistocene, Italian Pre-Alps): stratigraphy, palaeoenvironment and geological evolution. Quat. Int. 131, 35-58.

Reid, C., Reid, E.M., 1915. The Pliocene floras of the Dutch- Prussian border. Meded. Rijksopsp. Delfst. 6, 1-178.

Reid, E.M., 1920. Recherches sur quelques graines pliocénes du Pont-de-Gail (Cantal). Bull. Soc. Geol. France, ser. IV, 20, 48-87.

Rio, D., Raffi, I., Villa, G., 1990. Pliocene-Pleistocene calcareous nannofossil distribution patterns in the Western Mediterranean. In: Kastens, K., Mascle, J. (Eds.), Proc. ODP Science Results, Vol. 107, pp. 513-533. 
Rodríguez-Sánchez, F., Arroyo, J., 2008. Reconstructing the demise of Tethyan plants: climatedriven range dynamics of Laurus since the Pliocene. Global Ecol. Biogeogr. 17, 685-695.

Sala, B., Masini, M., 2007. Late Pliocene and Pleistocene small mammal chronology in the Italian peninsula. Quat. Int. 160, 4-16.

Sardella, R., Angelone, C., Barisone, G., Bedetti, C., Di Canzio, E., Marcolini, F., Squazzini, E., 2003. Italian Plio-Pleistocene mammal biochronology and correlation with marine sequences: three case studies. Il Quaternario 16, 15-20.

Shatilova, I., Rukhadze, L., Kokolashvili, I., 2014. The History of Genus Juglans L. on the Territory of Georgia. Bull. Georg. Nat. Acad. Sci. 8(2), 109-115.

Su, T., Liu, Y.S., Jacques, F.M.B., Huang, Y.J., Xing, Y.W., Zhou, Z.K., 2013. The intensification of the East Asian winter monsoon contributed to the disappearance of Cedrus (Pinaceae) in southwestern China. Quaternary Research 80, 316-325.

Svenning, J.C., 2003. Deterministic Plio-Pleistocene extinctions in the European cool-temperate tree flora. Ecol. Lett. 6, 646-653.

Szafer, W., 1961. Miocene Flora from Stare Gliwice in Upper Silesia. Prace Geol. Inst. Warszawa 33: 1-205.

Tallis, J.K., 1991. Plant community history. 398 pp., Chapman \& Hall, London. Torre, D., Albianelli, A., Azzaroli, A., Ficcarelli, G., Magi, M., Napoleone, G., Sagri, M., 1993. Paleomagnetic calibration of late Villafranchian and mammalian faunas from the upper Valdarno, Central Italy. Mem. Soc. Geol. It. 49, 335-344.

Thomasson, J.R., 1991. Sediment-borne "seeds" from Sand Creek, Northwestern Kansas: taphonomic significance and paleoecological and paleoenvironmental implications. Palaeog. Palaeoclim. Palaeoecol. 85, 213-225.

Torre, D., Albianelli, A., Bertini, A., Ficcarelli, G., Masini, F., Napoleone, G., 1996. Paleomagnetic calibration of Plio- Pleistocene mammal localities in Central Italy. Acta Zool. Crac. 39, 559-570.

Tralau, H., 1963. Asiatic Dycotyledonous affinities in the Cainozoic flora of Europe. K. svenska vetensk. Akad. Handl., Fjärde Ser., 9 (3), 1-84.

Tzedakis, P.C., Hooghiemstra, H., Pälike, H., 2006. The last 1.35 million years at Tenaghi Philippon: revised chronostratigraphy and longterm vegetation trends. Quat. Sci. Rev. 25, 34163430.

Utescher, T., Mosbrugger, V., 2015. The Palaeoflora Database: at http://www.palaeoflora.de [accessed on 26th Jan. 2015]

Utescher, T., Bruch, A.A., Micheels, A., Mosbrugger, V., Popova, S., 2011. Cenozoic climate gradients in Eurasia - a palaeo-perspective on future climate change? Palaeogeogr. Palaeoclimatol. Palaeoecol. 304, 351-358.

Utescher, T., Bruch, A.A., Erdei, B., François, L., Ivanov, D., Jacques, F.M.B., Kern, A.K., Liu, YS., Mosbrugger, V., Spicer, R.A., 2014. The Coexistence Approach-theoretical background and practical considerations of using plant fossils for climate quantification. Palaeogeogr. Palaeoclimat. Palaeoecol. 410, 58-73.

Vassio, E., Martinetto, E., 2012. Biases in the frequency of fruits and seeds in modern fluvial sediments in northwestern Italy: the key to interpreting analogous fossil assemblages. Palaios 27 , 779-797.

Velichkevich, F.Yu., Zastawniak, E., 2003. The Pliocene flora of Kholmech, south-eastern Belarus and its correlation with other Pliocene floras of Europe. Acta Palaeobot. 43, 137-259.

Venczel, M., Sanchíz, B., 2005. A fossil plethodontid salamander from the Middle Miocene of Slovakia (Caudata, Plethodontidae). Amphib. Reptil. 26, 408-411.

Wang, C.-W., 1961. The forests of China with a survey of grassland and desert vegetation. Maria Moors Cabot Foundation Publication, 5. Harvard University, Cambridge, MA.

Wing, S. L., Greenwood, D. R., 1993. Fossils and fossil climate: The case for equable continental interiors in the Eocene. Philos. T. Roy. Soc. B 341, 243-252. 
Wolfe, J.A., 1975. Some aspects of plant geography of the northern hemisphere during the late Cretaceous and Tertiary. Ann. Mo. Bot. Gard. 62, 264-279.

Xiang, Q.Y., Thomas, D.T., Zhang, W.H., Manchester, S.R., Murrell, Z., 2006. Species level phylogeny of the dogwood genus Cornus (Cornaceae) based on molecular and morphological evidence: implication in taxonomy and Tertiary intercontinental migration. Taxon 55 (1), 930.Xing, Y.-W., Utescher, T., Jacques, F.M.B., Tao, S., Liu, Y.-S., Huang, Y.-J., Zhou, Z.-K., 2012. Palaeoclimatic estimation reveals a weakwintermonsoon in southwestern China during the late Miocene: evidence from plant macrofossils. Palaeogeogr. Palaeoclimatol. Palaeoecol. 358-360, 1926.

Zachos, J., Pagani, M., Sloan, L., Thomas, E., Billups, K., 2001. Trends, rhythms, and aberrations in global climate $65 \mathrm{Ma}$ to present. Science 292, 686-693.

Zagwjin, W.H., 1990. Subtropical relicts in the Pliocene flora of Brunssum (The Netherlands). Geol. Mijnbouw 6, 219-225.

Zavala, C., Arcuri, M., Blanco Valiente, L., 2012. The importance of plant remains as diagnostic criteria for the recognition of ancient hyperpycnites. Revue de Paléobiologie, Vol. Spec. 11, pp. 457-469

Zhang, J.B., Li, R.Q., Xiang, X.G., Manchester, S.R., Lin, L., Wang, W., Wen, J., Chen, Z.D., 2013. Integrated fossil and molecular data reveal the biogeographic diversification of the Eastern Asian-Eastern North American disjunct hickory genus (Carya Nutt.). PLoS ONE 8 (7), 1-13.

Zhang, J.W., D’Rozario, A., Adams, J.M., Li, Y., Liang, X.Q., Jacques, F.M., Su, T., Zhou, Z.K., 2015. Sequoia maguanensis, a new Miocene relative of the coast redwood, Sequoia sempervirens, from China: Implications for paleogeography and paleoclimate. American Journal of Botany 102 (1), 103-118.

Figure captions

Figure 1 - Simplified geological scheme for the area of the San Lazzaro, Cava Toppetti and Dunarobba sections.

Figure 2 - Reference lithostratigraphic schemes for the South Valdichiana and Tiberino Basins (modified after Baldanza et al., 2014). 1=San Lazzaro; 2=Cava Toppetti II; 3=Dunarobba.

Figure 3 - Sedimentological/stratigraphic sections in the San Lazzaro area. Location of the biostratigraphic (dots) and carpological (FU3-6) samples is also reported. $\mathrm{t} D b=$ Discoaster broweri LO; bmG=medium-sized Gephyrocapsa sp. FO (sensu Raffi, 2002). CS = clay, silt; $\mathrm{G}=$ gravel.

Figure 4 - Panoramic view of the San Lazzaro quarry. The richest fruit and seed bearing deposit (FU5) was located at the transition from the grey to the yellowish sediments $(1 / 3$ above the bottom of the image).

Figure 5 - Detail of a lens of mixed shells and compressed phytodebris at ca. $8 \mathrm{~m}$ from the base of the San Lazzaro section (see FU4 in Fig. 3).

Figure 6 - Resumed geological setting, sedimentological interpretation, magnetostratigraphic and biochronological calibration, and fossil record for the Cava Toppetti II site (redrawn after Abbazzi et al., 1997). Original vertebrates taxonomy reported by Abbazzi et al. (1997) is not revised nor further discussed herein.

Figure 7 - Aspect of the deposits with compressed macroscopic plant remains in the Cava Toppetti II section as they appeared in the year 1998. The sampled fruit and seed bearing sediment (consolidated sandy mud, see NJ1 in Fig. 7) is shown in the detail below.

Figure 8 - Histograms of the percentage of HUTEA species in some well-dated early Pliocene to Early Pleistocene floras of Italy (dark grey bars). Records from San Lazzaro, Dunarobba and Cava Toppetti II are also reported (pale grey bars). Numbers indicate the total of HUTEA species in each assemblage. See label explainations and locality data in Table 2.

Figure 9 - Scheme summarizing the chronological distribution of carpological records of selected species in the Pliocene and early Pleistocene of northern-central Italy. The records from all the localities accessed into the CENOFITA database (Martinetto and Vassio, 2010; Martinetto et al., 
2015) are reported, according to data published by Basilici et al. (1997), Bertoldi and Martinetto (1995), Ghiotto (2010), Gregor (1990), Martinetto (1994, 1995, 1999, 2001a, 2001b, 2003, 2009, in press), Martinetto et al. (2015). Both the HUTEA and CTEA have been subsivided in groups according to the chronostratigraphic distribution, in such a way that the numbers 1 to 4 correponds to the Groups 1 to 4 in Martinetto et al. (2015). All of the species referred to the HUTEA and CTEA4 have been reported, whereas for the CTEA2 and CTEA3 only selected examples have been shown. The age range for each species is indicated by black bars for the records originating from reliably dated localities (Martinetto, 1999, 2001a, 2003; Martinetto et al., 2007, 2015): Lugagnano (5.1-4.5 Ma), Canale (4.5-3.8 Ma), Cherasco (4.5-3.8 Ma), Pocapaglia (4.5-3.8 Ma), Breolungi (5.13.8 Ma), Morozzo (5.1-3.8 Ma), Sento I (3.8-3.6 Ma), Candelo (4.5-3.6 Ma), Baldichieri-Fornace (3.8-3.3), Roatto (3.3-3.2 Ma), RDB Quarry of Villafranca d'Asti (3.3 to 3.1 Ma), Stura di Lanzo Fossil Forest (3.1-3.0 Ma), Marecchia (3.0-2.9 Ma), San Miniato (3.0-2.8 Ma), Castell'ArquatoMonte Falcone (3.0-2.8 Ma), Meleto (2.9-2.8 Ma), Santa Barbara (2.9-2.7 Ma), Castell'ArquatoArda-AD3 (2.5-2.4 Ma), Casnigo (2.1-1.9 Ma), Poggio Rosso (ca. 1.9 Ma), Santerno-Codrignano (1.8-1.7 Ma), Leffe 1st browncoal (1.6-1.4 Ma), Stirone-Laurano-LA1 (1.1-1.0 Ma), Enza-EZ38 (1.1-1.0 Ma), Ranica (1.1-1.0 Ma), Oriolo (1.0-0.8 Ma), Stirone-Laurano-LA3 (0.9-0.8 Ma), Pianico-BVC lithostratigraphic unit (0.8-0.7 Ma). Hatched bars indicate records from the following poorly dated localities (see Martinetto, 1999; Martinetto et al., 2015): Ca' Viettone (late Zanclean, possibly 3.8 to $3.6 \mathrm{Ma}$ ); Fossano (late Zanclean, possibly 4.0 to $3.6 \mathrm{Ma}$ ); Sento II (possibly late Zanclean, 3.8 to $3.6 \mathrm{Ma}$ ); Cossato (possibly late Zanclean-early Piacenzian, 3.8 to $3.2 \mathrm{Ma}$ ); Front (possibly Piacenzian, 3.3 to $3.0 \mathrm{Ma}$ ); Momello-Lanzo (possibly Piacenzian, 3.6 to $3.0 \mathrm{Ma}$ ); Castelletto Cervo I (possibly late Piacenzian, 2.8 to $2.6 \mathrm{Ma}$ ); Castelletto Cervo II (possibly Gelasian, 2.6 to 2.0 Ma); San Pietro di Ragogna (Gelasian, 2.6 to $1.8 \mathrm{Ma}$ ); Buronzo (possibly Gelasian, 2.2 to $1.8 \mathrm{Ma}$ ); Steggio (Calabrian, 1.8 to $0.8 \mathrm{Ma}$ ). Abbreviations: $\mathrm{c}=$ climber; $\mathrm{h}=\mathrm{herb}$; MAT $=$ Mean Annual Temperature; Mes = Messinian; MP = Middle Pleistocene; NLR = Nearest Living Relative; $\mathrm{s}=$ shrub; $\mathrm{t}=$ tree.

Table 1 - Mean Annual Temperature lower threshold values for modern plant genera or subgeneric taxa extinct in Europe ("exotic"), according to the Paleoflora database (PFDB, Utescher and Mosbrugger, 2015), the GrimClim database (CG, Grimm and Denk, 2012), and to different literature sources listed in Appendix 1 (Alternative MATmin). The list is limited to taxa of the HUTEA and CTEA categories with a proved occurrence in the late Cenozoic of Italy, selected as a representative territory for the evaluation of the southern European floral change.

Table 2 - List of the reference localities selected for the calculation of HUTEA species percentage reported in Fig. 8.

Table 3 - Occurrence of HUTEA and CTEA genera in the main Early Pleistocene carpofloras of Europe.

Table 4 - List of the carpological taxa identified in four sediment bulk samples from the San Lazzaro section, see Fig. 3. In brackets the number of specimens for each species. 